\title{
Late Quaternary Activity of the La Rinconada Fault Zone, San Juan, Argentina
}

Jeremy M. Rimando ${ }^{1,2^{*}}$, Lindsay M. Schoenbohm ${ }^{1,2}$, Carlos H. Costa ${ }^{3}$, Lewis A. Owen $^{4}$, Jason M. Cesta ${ }^{4}$, Andres D. Richard ${ }^{5}$, Carlos E. Gardini ${ }^{3}$

${ }^{1}$ Department of Earth Sciences, University of Toronto, Toronto, Ontario M5S 3B1, Canada

${ }^{2}$ Department of Chemical and Physical Sciences, University of Toronto Mississauga, Mississauga, Ontario L5L 1C6, Canada

${ }^{3}$ Departamento de Geologia, Universidad Nacional de San Luis, 5700 San Luis, Argentina

${ }^{4}$ Department of Geology, University of Cincinnati, Cincinnati, OH 45221, USA

${ }^{5}$ Consejo Nacional de Investigaciones Científicas y Técnicas (CONICET), Ejército de los Andes 950, 5700 San Luis, Argentina

${ }^{*}$ Corresponding author: jeremy.rimando@mail.utoronto.ca (J. Rimando)

\section{Key points:}

-The La Rinconada Fault (LRF) in San Juan, Argentina has a late Quaternary average shortening rate of $0.41 \pm 0.01 \mathrm{~mm} / \mathrm{yr}$.

\section{Abstract}

Most of the permanent deformation in the Pampean Flat slab segment of the Central Andes is taken up at the Andean Orogenic Front in Argentina, a narrow zone between the Eastern Precordillera and Sierras Pampeanas that comprises one of the world's most seismically active thrust zones. Active faults and folds in the region have been extensively mapped but still largely lack information on style and rates of deformation, which is essential for understanding the distribution of regional strain and estimating the seismic potential of individual faults. Structural, geomorphic, and ${ }^{36} \mathrm{Cl}$ cosmogenic radionuclide surface exposure ages methods are used to focus on key sites along the 30-km-long La Rinconada Fault Zone in this region of westcentral Argentina, which is $\sim 15 \mathrm{~km}$ away from the highly-populated $(\sim 500,000)$ city of San Juan, to define a late Quaternary average shortening rate of $0.41 \pm 0.01 \mathrm{~mm} / \mathrm{yr}$. This slip rate is the same order of magnitude, but slightly lower than nearby similar east-dipping Eastern Precordillera faults including the La Laja and Las Tapias faults. Relatively low slip-rates are interpreted as being a consequence of distributed deformation between the latitude of the La Rinconada Fault Zone ( 31 and $32^{\circ} \mathrm{S}$ ), as compared to between latitudes 32 to $33^{\circ} \mathrm{S}$ where deformation appears to be focused on fewer structures, including the Las Peñas and La Cal Thrust faults. The La Rinconada Fault Zone is capable of generating earthquakes of $M_{W} 6.6-7.2$, but further investigations are required to determine timing and recurrence intervals of discrete events.

This article has been accepted for publication and undergone full peer review but has not been through the copyediting, typesetting, pagination and proofreading process which may lead to differences between this version and the Version of Record. Please cite this article as doi: $10.1029 / 2018 T C 005321$ 


\section{Introduction}

Permanent shortening in the Pampean flat-slab segment of the South American plate has occurred mostly in doubly vergent fold-and-thrust belts (Armijo et al., 2010; Riesner et al., 2018) in the back-arc region since $20 \mathrm{Ma}$ (Baby et al, 1997; Zapata and Allmendinger, 1996), including the Argentine Precordillera (Fig. 1). Some 60$75 \%$ of the total shortening between the trench and the foreland at $30^{\circ} \mathrm{S}$ has been accommodated within the Precordillera during the past 10-15 Ma (Allmendinger et al., 1990). Shortening has also been accommodated in the Sierras Pampeanas, a region of thick-skinned deformation directly to the east at the same time as deformation was active in the Precordillera. This partitioning of deformation has been related to the presence of flat-slab subduction from 27 and $33.5^{\circ} \mathrm{S}$ (Ramos, 1988; Ramos, 1998; Ramos et al., 2002; Ramos et al., 2004; Ramos and Folguera, 2009). Deformation in the Precordillera proceeded from west to east and reached the Eastern Precordillera at $\sim 2.6 \mathrm{Ma}$. In contrast, uplift of basement rocks of the Sierras Pampeanas propagated westward, beginning $\sim 6-5.5 \mathrm{Ma}$ at its eastern extent, and reaching the Pie de Palo near its western extent $\sim 3$ Ma (Jordan et al., 1983a, b; Ramos et al., 2002) (Fig. 1). Presently, the oppositely-verging Precordillera and Sierras Pampeanas terranes are juxtaposed between latitudes 30 and $32^{\circ} \mathrm{S}$ across a relatively narrow $(\sim 50 \mathrm{~km})$ zone of active mountain building called the Andean Orogenic Front (Fig. 1).

Evidence for highly-localized back-arc deformation along the Andean Orogenic Front includes GPS gradients, the location of shallow crustal seismicity, and Quaternary offset on faults (Fig. 2). Most prominent Quaternary deformation features (Fig. 2) have been recorded across the Andean Orogenic Front (Cortés et al., 1999; Costa et al., 2000, 2006, and references therein). Since most of the crustal thickening in the Andes during the Neogene has been caused by tectonic shortening of the South American plate (Allmendinger et al., 1997; Isacks, 1988; Kley and Monaldi, 1998; Ramos, 1988; Ramos et al., 1996), study of the distribution and rates of movement along active tectonic structures in this area is relevant to the understanding of ongoing mountain building, partitioning of strain, and crustal deformation related to flat-slab subduction. However, the spatio-temporal coverage and/or resolution of these data sets are limited. For instance, interpretation of GPS-derived slip-rates across individual structures is currently impossible due to the sparseness of GPS stations. Further, the activity of most of the structures in the Precordillera and the Sierras Pampeanas have not been quantified since there is still a paucity of studies employing geochronological techniques to determine slip rates (Costa et al., 2015a and references therein).

This study reports the Quaternary uplift and shortening rates of the La Rinconada Fault Zone from cosmogenic dating of recently offset landforms, which in addition to its tectonic significance, lies only $15 \mathrm{~km}$ south of the city of San Juan which has a population of $\sim 100,000$. In 1944 the city was shaken by a $M_{W} 7$ earthquake 
associated with the La Laja Fault, located $15 \mathrm{~km}$ north of the city. This event resulted in the death of 10,000 people, $10 \%$ of its population at the time (Castellanos, 1945; Groeber, 1944; Harrington, 1944; INPRES, 1977). From preliminary assessment, the La Rinconada Fault may also be capable of posing similar hazards to the city considering at least its length and proximity to the city.

The slip rates determined in this study, together with existing slip rates for other faults, are used to interpret the role of the La Rinconada Fault in the regional tectonic context, and in particular the proportion of total shortening it accommodates in the Andean Orogenic Front of the flat slab segment from latitudes 30 to $33^{\circ} \mathrm{S}$. We also estimate the potential for the La Rinconada Fault to generating $\geq M_{W} 7$ earthquakes in or near the city of San Juan.

\section{Background}

\subsection{Regional tectonic setting}

Ongoing subduction of the Nazca plate beneath the South American plate is primarily responsible for building the Andean orogenic belt-the world's longest and highest non-collisional continental mountain range. However, the Pampean segment $\left(27-33^{\circ} \mathrm{S}\right)$ of the Central Andes subduction zone is abnormally shallow, the result of subduction of the Juan Fernandez Ridge (Pilger, 1981), with the slab extending as far as $300 \mathrm{~km}$ into the continental interior at a shallow depth of $\sim 100 \mathrm{~km}$ (Cahill and Isacks, 1992; Engdahl et al., 1998; Gutscher et al., 2000; Jordan et al., 1983a, b; Ramos, 1999; Smalley et al., 1993). As a result, the Pampean segment displays a distinct tectonic style and distribution of Quaternary deformation. In particular, in addition to the development of a

fold-and-thrust belt at the plate boundary, deformation has penetrated deeply into the intraplate region (Gutscher et al., 2000) either through thermal weakening of the crust due to eastward migration of arc magmatism (Ramos et al., 2002) or increased interplate coupling between the flat-slab segment and the rheologically strengthened upper lithosphere (due to cooling), resulting in a series of uplifted basement ranges known as the Sierras Pampeanas (Fig. 1). The Sierras Pampeanas are a modern analogue of the Laramide Orogen in the western US (Jordan et al., 1983a, b; Jordan and Allmendinger, 1986; Smalley et al., 1993).

GPS studies indicate a convergence rate of $6.3 \mathrm{~cm} / \mathrm{yr}$ along the plate boundary of the flat-slab segment (Brooks et al., 2003; Kendrick et al., 2003). Deformation along the plate boundary has migrated east through time, from the Principal Cordillera, to the Frontal Cordillera, and finally to the Precordillera (Fig. 1; Jordan et al., 1983a, b; Jordan and Gardeweg, 1989; Ramos, 1988; Ramos et al., 2002; Zapata and Allmendinger, 1996). Between latitudes 30 and $32^{\circ} 10^{\prime} \mathrm{S}$, the well-documented Argentine Precordillera can be further divided into western, central, and eastern 
structural provinces (Baldis et al., 1982; Ortiz and Zambrano, 1981), separated by basins filled with late Tertiary and Quaternary continental sediments (von Gosen,1992; Jordan et al., 1993). The Western and Central Argentine Precordillera are both thin-skinned. The Eastern Precordillera arguably transitions from thinskinned to thick-skinned from west to east (Siame, 2015). However, convincing evidence of this transition, so far, is available only north of Pie de Palo (Allmendinger and Judge, 2014; Zapata and Allmendinger, 1996). The Eastern Precordillera formed through Pliocene-Pleistocene orogenic activity (Jordan et al., 1993; Ramos, 1988).

At present, the active Andean Orogenic Front is located in between the eastern foothills of the mainly east-vergent, thin-skinned Argentine Precordillera fold-andthrust belt and the mainly west-vergent, thick-skinned Sierras Pampeanas uplifted basement blocks (Fig. 1; Brooks et al., 2003; Costa, 1999; Fielding and Jordan, 1988; Groeber, 1944; Kadinsky-Cade et al., 1985; Meigs et al., 2006; Ramos et al., 1997; Siame et al., 2002; Siame, 2005; Siame et al, 2015; Smalley et al., 1993; Uliarte et al., 1987; Vergés et al., 2007). GPS-derived velocity fields suggest rates of back-arc deformation between the Eastern Precordillera and the Western Sierras Pampeanas range from 2 to $7 \mathrm{~mm} / \mathrm{yr}$ (Kendrick, et al. 2006; Kendrick, et al., 1999, 2001, 2003; Brooks et al., 2003). This flat subduction segment is characterized by the juxtaposition of oppositely-verging thrust systems in the back-arc region that show evidence of localized Quaternary-active deformation, but with deformation concentrated at the juncture between these regions. GPS studies have proposed that strain localization is accomplished through a microplate which overthrusts both the Nazca and South American plates and deforms primarily at its boundaries rather than throughout the entire back-arc contractional wedge (Brooks et al., 2003).

Approximately $90 \%$ of the documented Quaternary deformation in Argentina is located within the Andean Orogenic Front (Costa et al. 2006). Quaternary deformation is characterized mostly by north-south oriented reverse faults and folds and, to a lesser extent, north-south oriented strike-slip faults resulting from partitioning of the oblique convergence of the Nazca and South American plates (Costa et al., 2000; Siame, 1997, 2005). This segment is also characterized by high levels of shallow (5-35 km) crustal seismicity (Fig. 2) (Smalley and Isacks, 1990; Smalley et al., 1993), with earthquake seismic moments reaching 3 to 5 times larger than in subduction segments where the slab is dipping $\geqq 30^{\circ}$ (Gutscher et al., 2000; Jordan et al., 1983a, b; Ramos et al., 2002; Smalley et al., 1993). The distribution of shallow earthquake hypocenters is spatially related to structures with evidence of recent deformation between the Precordillera and the Sierras Pampeanas (Cahill and Isacks, 1992; Engdahl et al., 1998; Gutscher et al., 2000; Smalley et al., 1993). San Juan and Mendoza provinces have been the locus of large-magnitude earthquakes in the past century. Some notable examples of earthquakes which are associated with surface ruptures are the $1944 M_{W} 7.0$ San Juan earthquake that was 
generated along the La Laja fault (Castellanos, 1944; Groeber, 1944; and Harrington, 1944) and the $1977 M_{s} 7.4$ Caucete earthquake that occurred along the Ampacama- Niquizanga fault (Bastías, 1985; Volponi et al., 1978). There are also large magnitude earthquakes such as the $1952 M_{W} 6.8$ San Juan earthquake, for which the seismogenic structure has been suspected but not been identified (Alvarado and Beck, 2006; INPRES, 1977).

\subsection{La Rinconada Fault Zone}

The LRFZ (Figs. 3 and 5), parallel to the Villicum-Zonda-Pedernal Thrust faults and along strike with the Cerro Salinas Fault to the south is a north-south trending, 30-km-long, east-dipping reverse fault located southwest of the city of San Juan (Bastias et al., 1990; Costa et al., 2006; Martos 1987; PMA: GCA, 2008), a city which has been hit by at least $3>M_{w} 6.8$ earthquakes in the past 100 years (Alvarado and Beck, 2006). Prominent fault scarps, $>20 \mathrm{~m}$ high, are a consequence of these earthquakes and are counterslope to the eastern flank of the Eastern Precordillera, particularly the foothills of the Sierra Chica de Zonda (Fig. 4). These scarps uplift and expose the east-dipping Miocene Lomas de las Tapias bedrock, which is also being uplifted along the La Laja Fault (Rockwell et al., 2014). The La Rinconada scarps, which most probably represent cumulative displacement, cut through multiple levels of well-preserved alluvial deposits, comparable to neighboring Quaternary-active faults (e.g., La Laja, Las Tapias, and Cerro Salinas faults). The La Rinconada Fault also exhibits smaller scarps ( 2 $\mathrm{m}$ high) which have been linked to the $1952 M_{W} 6.8$ San Juan earthquake on the basis of this faults proximity to the epicentral location (Tello and Perucca, 1993; PMA: GCA, 2008; Yeats, 2015). The rate of movement of the La Rinconada Fault has not been established, nor has a relationship to the 1952 San Juan earthquake been proven. Based on its potential seismogenic history, long trace, and large, multiple-event scarps, the La Rinconada Fault is an ideal target for neotectonic studies and seismic hazard assessment that will allow us to determine its contribution to the ongoing deformation of the Andean Orogenic Front and estimate the seismic hazard it poses to the city of San Juan.

\section{Methods}

\subsection{Geomorphic and Geologic Mapping}

High-resolution satellite images from Land Remote-Sensing Satellite (LANDSAT), Google Earth, and 30-m-resolution Advanced Spaceborne Thermal Emission and Reflection Radiometer (ASTER) global digital elevation models (GDEM) (https://asterweb.jpl.nasa.gov/gdem.asp) served as base for mapping structural, geologic and geomorphic features observed in the field. The geology of the area 
transected by the La Rinconada Fault was mapped primarily at a scale of 1:50,000 (Fig. 4). Geomorphic maps focused on two sites: the El Molino and Arbol Quemado sites, which highlight the distribution of Quaternary landforms/deposits and deformation (faulting, folding, warping) features, were mapped with at a scale of at least 1:10,000. Different cut and fill strath terraces were identified on the basis of surface morphology, stratigraphic relationships, and weathering characteristics (McFadden et al., 1989; Owen et al., 2014). We used the letter $Q$ to indicate Quaternary, followed by a number $(1,2 \ldots n)$ from youngest to oldest, and lastly a letter to indicate the study area (e.g., $m$ for Molino).

\subsection{Differential global positioning system (DGPS) survey and topographic profile construction}

Fault scarp topographic profiles were surveyed with sub-centimeter precision using a Trimble $\AA^{8}$ R3 DGPS survey system which includes a base station and two rover units.

Five surfaces which are cut by the La Rinconada fault at the El Molino Site and 7 surfaces cut by the Arbol Quemado fault were surveyed using this method. Geographic coordinates and elevation data were gathered by walking along a nearly perpendicular path across the scarps using the DGPS rovers which were held at constant height above the ground and set at a one-second data collection rate. For the duration of each survey, the base station received signals from satellites which provided information that allowed for post-processing correction of data from the rovers. The surveys on both sides of the fault scarps were extended, where possible, for several tens of meters to also capture the regional slope (Fig. S1) of the surface.

Post-processing of data gathered in the field was performed using Trimble Business Centre 2. Survey points were projected on lines perpendicular to the fault trace using the point profile interactive tool on ESRl's ArcMap to adjust the minor irregularities in the traces of survey paths or variations in transit speed.

\subsection{Displacement measurement}

Topographic profiles across scarps in the El Molino and Arbol Quemado sites that were obtained through kinematic GPS survey were used to measure displacement. Two methods were used to explore a possible range of displacement values: 1) solving equations by Yang et al. (2015), which are based on geometric relations between the fault and the displaced surfaces, and 2) FaultFoldForward (FFF) trishear modelling. 
At the El Molino site, displacement on fault scarps displaying fault-bend folding was measured using the FFF modelling software (v.7.1.1) by Allmendinger (1998) (http://www.geo.cornell.edu/geology/facultyRWA/programs/faultfoldforward.html; last accessed April 2017). FFF software, which is based on the trishear concept (Allmendinger 1998; Allmendinger and Shaw 2000; Cardozo 2003; Erslev, 1991; Hardy and Ford, 1997; Hardy and McClay, 1999; Zehnder and Allmendinger, 2000), allows the creation of forward models of area-balanced cross-sections with complicated fault-fold geometries using six trishear parameters first described by Erslev (1991), which include displacement, fault ramp angle, trishear apical angle (TA), propagation to slip (P/S) ratio, and the $X$ and $Y$ position of the tip line. The poorly consolidated, dominantly, coarse pebble-to-gravel sized sediments which comprises the horizon that was surveyed and modelled satisfies the assumption that material must be isotropic and homogenous (Johnson and Johnson, 2002; Cardozo et al., 2003; Hardy and Finch, 2007).

A series of forward models were created using different combinations of trishear parameters and were compared by visual inspection to faulted profiles that were uploaded as background in the FFF program window. Quantifiable error for displacement estimates from trishear modelling is not yet available for the current version of the FaultfoldForward (FFF) modelling software by Allmendinger (1998) (http://www.geo.cornell.edu/geology/facultyRWA/programs/faultfoldforward.html; last accessed Dec 2018) Using an iterative approach, the range of possible values of trishear parameters, were narrowed to specific values that created a model which closely resembles the faulted profile in terms of height and backlimb inclination. Different scarp morphologies were also modelled to test for the effect of assumed scarp morphology on the amount of displacement. Prior to running the models, the surface was rotated to account for regional slope (Fig. S1) of the terraces measured in the field.

The amount of displacement is the amount of slip associated with the model that best matches the faulted profile. However, uncertainty for the displacement measurements cannot be quantified because best fit is based on visual inspection. Several studies which use FFF modelling as one of the approaches to measure displacement on reverse fault scarps also in Argentina used this same trial-anderror and visual estimation approach for determining the model that best fits the actual faulted profile (Costa, et al., 2015; Vazquez et al., 2016). Using the fault dip value at the surface, the displacement was then resolved into components of shortening and uplift.

For the Arbol Quemado site, where the original scarp morphology is uncertain, both FFF modelling and Yang et al. (2015)'s equations were used to measure a likely range of displacement values. FFF accounted for possible involvement of varying degrees of fault-related-folding while Yang et al. (2015)'s method assumed an original simple reverse fault scarp morphology. Input parameters for Yang et al. 
(2015)'s method were the following: slope and y-intercept values from linear regressions of hanging wall, footwall, and scarp surface survey points; fault dip; and fault-tip X-axis position. For measurement of displacement on all fault scarps, the same dip value $\left(33^{\circ}\right)$ was used and the fault tip position was placed near the base of each scarp, as was observed in the stream cut exposure of the Q9a scarp (Fig. 5B).

For propagation of error associated with these parameters, a Monte Carlo simulator was used (by Brian Murphy, September 2013; https://drive.google.com/file/d/0B3Xb1yYamd6iZUIBYUJIRU

$5 \mathrm{rWTg} / \mathrm{view}$; last accessed May 15, 2017). This required specifying the equation for displacement, and the input values, distribution types, and errors for the different variables. The fault-tip $x$-axis position followed a uniform distribution while all the other variables followed a normal distribution. The estimate of the true value of displacement and its associated uncertainty was then taken from the average of 10,000 realizations. For each of the calculations, a 1 sigma uncertainty of $\pm 2^{\circ}$ and \pm 1 $m$ was assigned for the dip and the $x$-axis position of the fault tip, respectively. The uncertainty corresponding to the slope and $y$-intercept values of the hanging wall, footwall, and scarp surface regression were taken from the linear regression statistics and were also input in the Monte Carlo simulations.

Trenching was also performed to expose a sectional view of the small faultpropagation fold scarp at the base of the series of cumulative scarps at the El Molino site (Fig. 10A). Displacement was measured directly from the offset bedrock. Precise inverse modelling of the fault propagation-folding was not performed due to the difficulty of delineating deformed layers of the coarse alluvial material.

\section{4. ${ }^{36} \mathrm{Cl}$ Cosmogenic radionuclide surface exposure dating}

Cosmogenic radionuclide dating (Lal, 1988, 1991; Gosse and Phillips, 2001; Stone et al., 1998) for surface exposure ages was combined with geomorphic analysis of fault scarps to estimate prehistoric slip rates. The ages of the carbonate-dominated strath terraces of the El Molino and Arbol Quemado sites were calculated by measuring the concentration of ${ }^{36} \mathrm{Cl}$, a spallation product of either $\mathrm{Ca}$ or $\mathrm{K}$ (Phillips et al, 1990), coupled with the production rate of ${ }^{36} \mathrm{Cl}$ for the altitude and latitude of the sample site (Lal, 1988, 1991; Gosse and Phillips, 2001; Stone et al., 1998).

Since alluvial surfaces were dated, inheritance is likely (Blisniuk et al., 2012; Owen et al., 2011). To account for this, samples were collected and measured at different depths, allowing the construction of depth profiles. Production rates are usually highest at the surface and decrease exponentially with depth to zero; decay to a non-zero concentration indicates the inherited component, which can be used to correct for surface concentrations (Anderson et al., 1996; Perg et al., 2001). Approximately 2-m-deep pits were excavated on terrace T2 at the El Molino site and on terrace T9 at the Arbol Quemado site. Samples of $2 \mathrm{~kg}$ of coarse-sand to granule- 
sized sediments (2-4 $\mathrm{mm}$ ) of mixed lithology (carbonate and metasedimentary rocks) were gathered each at depths of $25,50,75,100$, and $150 \mathrm{~cm}$ at each site.

For the remainder of offset surfaces dated in this study, 100 pebble- to cobble-sized (4-6 cm average diameter) pure carbonate surface samples were gathered from each surface of which $\sim 25$ were selected for dating. For this type of sampling, inheritance is constrained by gathering samples from the modern channel and subtracting the inherited nuclide concentration measured from these modern channel samples (Anderson et al., 1996; Repka et al., 1997). Both depth profile and surface samples were collected from the Q2m surface to assess agreement among methods.

Extraction, chemical preparation, and dissolution of samples was performed at the Cosmogenic Nuclide Laboratories in the Department of Geology at the University of Cincinnati, USA, following the procedures of Stone et al. (1996), which were modified as in Cesta and Ward (2016) to help hasten the dissolution process. The selected surface samples were amalgamated, while the depth profiles samples were mixed before being crushed and sieved to obtain the $<250 \mu \mathrm{m}$ fraction. Approximately $100 \mathrm{~g}$ of each of the pure carbonate surface samples and $\sim 180 \mathrm{~g}$ of each of the mixed lithology depth profile samples were leached with dilute $\mathrm{HNO}_{3}$, rinsed, and then dried. A larger amount was needed from the depth profiles to make up for the lower proportion of carbonate content. Approximately $30 \mathrm{~g}$ of the leached $<250 \mu \mathrm{m}$ fraction of surface and depth profile samples was prepared for dissolution. Approximately $1 \mathrm{~g}$ of ${ }^{35} \mathrm{Cl}$ enriched (or "spike") carrier solution from Icon Isotopes, New Jersey was added to each sample. HF and trace metal grade (TMG) $\mathrm{HNO}_{3}$ and were then added for sample digestion. $\mathrm{AgCl}$ was precipitated and

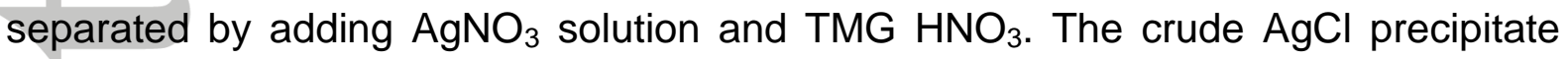
was then dissolved with TMG $\mathrm{NH}_{4} \mathrm{OH}$ to produce a solution that was separated through anion exchange chromatography. The final $\mathrm{AgCl}$ product was rinsed, dried, and then loaded into $\mathrm{Cu}$ cathode holders packed with $\mathrm{AgBr}$. These targeted samples, along with the carrier solution blanks, were sent to Purdue Rare Isotope Measurement (PRIME) Laboratory at Purdue University, USA for measurement of ${ }^{36} \mathrm{Cl} / \mathrm{Cl}_{\mathrm{T}}$ and ${ }^{35} \mathrm{Cl} /{ }^{37} \mathrm{Cl}$ using Accelerator Mass Spectrometry (AMS) analysis.

Each leached sample having a mass of $13 \mathrm{~g}$ and selected pre-leached surface and depth profile samples were set aside and sent to Bureau Veritas Minerals, Vancouver, Canada for whole rock analysis using lithium metaborate fusion. Refractory and rare earth elements were analyzed through Inductively Coupled Plasma Mass Spectrometry (ICP-MS). Whole rock major and minor elements were analyzed through Inductively Coupled Plasma Emission Spectrometry (ICP-ES). Total carbon and total sulphur analysis was performed using a LECO analyzer. Trace boron was analyzed through a Sodium Peroxide Fusion ICP-MS finish. 
The topographic shielding factor was calculated using the CRONUS-Earth (CosmicRay Produced Nuclide Systematics on Earth) Topographic Shielding Calculator v2.0 (http://cronus.cosmogenicnuclides.rocks/2.0/; last accessed June 21, 2017).

Ages of surfaces from surface clasts and depth profile samples were computed using the ${ }^{36} \mathrm{Cl}$ CRONUS-Earth Web calculator v. 2.0 (http://cronus.cosmogenicnuclides.rocks/2.0/html/cl/; last accessed in July 2017) and the MATLAB-based CRONUSCalc depth profile calculator (https://bitbucket.org/cronusearth/cronus-calc/; last accessed September 7, 2017), respectively, both of which are by Marrero et al. (2016). The 'Lal/Stone' timedependent scaling scheme (Lal, 1991; Stone, 2000) was used. As for erosion rate input, which can influence the surface clast age calculation, we assume a $0 \mathrm{~mm} / \mathrm{ka}$ erosion rate for the calculation of surface clast ages since no direct method for measuring erosion rates was conducted at this site. We justify our assumption of zero erosion with our observation of desert varnish and large rounded clasts. Similar to previous studies in the area (e.g., Hedrick et al., 2013; Siame et al., 2015), while assuming a $0 \mathrm{~mm} / \mathrm{ka}$ erosion, we also show the potential effect of assuming different erosion scenarios on the surface clast ages we calculate. For depth profiles, erosion rates are already calculated along with inheritance. Approximately $92 \%$ of in situ ${ }^{36} \mathrm{Cl}$ in our surface clast samples was produced through $\mathrm{Ca}$ spallation. Detailed information necessary for the calculation of ages is shown in Tables $\mathbf{1}$ and 2. For naming samples (See Tables 1 and 2), we used the letter $R$ for samples from surfaces offset by the main Rinconada fault trace at El Molino site and $Q$ for samples from surfaces offset by the subsidiary fault at Arbol Quemado. The letter D or $S$ indicates whether it is a depth numbers to indicate different profile or surface clast sample. And lastly, we used $50 \ldots n)$.

\section{Site Analysis}

\subsection{Site 1: El Molino}

The counterslope, west-facing scarps of the La Rinconada Fault are clearly visible, particularly where they are more continuous in its northern portion. At the El Molino site, which is $\sim 3 \mathrm{~km}$ south of the northern fault terminus, the scarps of the main fault trend $\mathrm{N} 30^{\circ} \mathrm{W}$ and reach heights of $\sim 23 \mathrm{~m}$. These displace a series of strath terraces composed of late Quaternary alluvium. A much smaller fault propagation fold scarp ( $2 \mathrm{~m}$ high) (Fig 4A, and Fig. 8) is also found $<100 \mathrm{~m}$ west of, and parallel to the main trace, locally forming a forward-breaking sequence. The La Rinconada Fault appears to reflect pure reverse faulting, due to the lack of evidence of laterally displaced terrace risers at this site or elsewhere along the La Rinconada Fault, although a strike-slip component cannot be entirely ruled out. A sectional view of the scarp of the main fault trace is exposed in a stream cut (Fig. 5A). The $40^{\circ} \mathrm{E}$-dipping fault dip follows the bedding orientation of the Loma de las Tapias Formation. The 
bedding orientation of the Loma de las Tapias Formation decreases towards the east; if the La Rinconada fault continues to follow a bedding plane, it may therefore have a listric geometry. Although not unambiguous, evidence for a surfacerupturing fault scarp is that the Lomas de las Tapias bedrock is thrust over the Q2m alluvium surface, exhibiting a hanging wall-collapse scarp type (Fig. 6). Distinguishing whether the LRF scarps are large cumulative scarps or fold scarps is important because the measured displacement in the FFF modelling will be different for these two scenarios. This scarp could also be formed by a flat-ramp-flat fault geometry, but this is unlikely because such a geometry would be reflected in much steeper backlimb inclination. Similarly, identifying the 2-m-high scarp as a fault-propagation fold, instead of a regular surface-rupturing, thrust fault scarp, changes how we measure its amount of displacement. Scarp geometry and the amount of displacement of this fault propagation fold to the west of the cumulative scarp of the LRF is discussed in more detail in section 4.1.3.

\subsubsection{Geomorphic Surfaces}

The El Molino site was chosen because of the presence of large cumulativedisplacement fault scarps that cut through multiple levels of aerially extensive, wellpreserved strath and fill terraces. Three levels of displaced strath terraces (Q2m, Q3m, and Q4m) and a fill terrace (Q5m) were identified (Fig. 7), the upthrown side of these surfaces standing 10 to 20 meters above the stream. The relatively small difference in heights above the stream despite the large differences in the amount of displacement for each terrace is due to the general downward slope of the terrain towards the north, and the progressive cutting of younger terraces to the north. The intersection of terrace risers and upper terrace treads on successive terrace levels serve as ideal piercing points for measurement of displacement.

The strath terrace deposits are composed of pebble- to cobble-sized polymictic clasts that include both carbonate and lithic shale lithologies and are imbricated to the east. Due to the semi-arid climate of the Eastern Precordillera, the surfaces show evidence of deflation, wherein the topmost layer (up to $\sim 5 \mathrm{~cm}$ ) is devoid of finer sediments. The clastic sources for alluvial material are the limestones of the Cambrian Marquesado group and the shales of the Silurian Rinconada formation which are found on the eastern flank of the Sierra Chica del Zonda. Material is transported by channels flowing from west to east.

The terraces have a regional dip of around $3-4^{\circ}$ to the east and $4-5^{\circ}$ to the north, and unconformably overlie the Miocene Loma de las Tapias Formation. The surface of the topographically lowest strath terrace (Q2m) is composed of poorly sorted, semi-angular to angular sediments, which exhibit a clast-supported fabric while the highest (Q5m) strath terrace is characterized by well sorted, consistently angular sediments, which also exhibit clast-supported fabric. Q5m has noticeably more 
clasts that have desert varnish compared to Q2m. The higher degree of sorting and angularity can be attributed to the more extensive in-situ mechanical weathering of large clasts into smaller clasts through time and the development of desert pavement.

Except for Q2m, strath terraces are absent in the footwall to the west of the fault. One possibility is that they were formed initially but have subsequently been removed by erosion. However, there is no evidence of degraded or obscured footwall terraces or of lateral abrasion. Alternatively, incision may solely reflect hanging wall uplift, and therefore the surface to the west of the fault may have been continuously occupied during formation of the hanging wall terraces. Finally, if the region to the west of the fault is experiencing relative subsidence (either due to subsidence or footwall aggradation) equivalent strath terraces may be buried. While there is no evidence to establish which scenario is more likely, the match in cosmogenic ages between the Q2m surfaces on either side of the main fault (see section 4.1.2 below) argue that true displacement can be calculated for at least this surface. Additionally, the thickness of the strath covering material is identical on the upthrown and downthrown side of the fault. Considering that the footwalls of the older surfaces may have been modified by subsequent alluviation, by using the present Q2m footwall elevation in our displacement calculations for all surfaces, we may be underestimating the amount of displacement for the Q3m, Q4m, and Q5m surfaces. Therefore, our displacement calculations are likely a minimum. (see section 4.1.3 below). Similar offset hanging wall strath terraces without paired footwall terraces were used along the Las Tapias Segment of the Villicum-ZondaPedernal thrust fault, which is located on the western flank of the Sierra Chica del Zonda, to determine fault slip rates (Siame 2002).

\subsubsection{Ages}

In computing ages of surfaces from surface clasts, we assumed zero erosion, due to the well-preserved surface as indicated by presence of desert varnish. Previous work done in nearby areas in the Eastern Precordillera and Western Sierras Pampeanas (Hedrick et al., 2013; Schmidt et al., 2011; and Siame et al., 2002) also assume zero erosion. In arid environments such as this, it is more likely for computed ages of surfaces to be older due to inheritance rather than younger due to erosion.

For surface Q2m which is on the hanging wall side of the larger cumulative fault scarp (eastern trace), both surface clasts and depth profile samples to a depth of $150 \mathrm{~cm}$ were collected. The surface clasts yielded an age of $36.9 \pm 0.8 \mathrm{ka}$, and modelling of the depth profile samples (Fig. 8) yielded an age of $34.5^{-3.1} /+3.0 \mathrm{ka}$, an inheritance equivalent to $31.8^{-1.5} /+1.4 \mathrm{ka}$ of prior exposure, and an erosion rate of $0.11 \mathrm{~mm} / \mathrm{ka}$ (which is consistent with the prevalence of desert varnish). Only 3 samples were modelled for the depth profile age because there were no results for 
the samples at 50 and $100 \mathrm{~cm}$ depths. The ages from both sampling methods on Q2m are in good agreement and suggest that surface clast ages in this locality are reliable. The rest of the ages in this locality are based on dating of surface clasts. The part of surface Q2m which is on the footwall side of the larger cumulative fault scarp (eastern trace) and in the hanging wall of the smaller, probably most recent scarp (western trace) of the La Rinconada Fault, yielded an age of $41.4 \pm 0.9 \mathrm{ka}$. This slightly older age could be interpreted either as possibly resulting from incorporation of colluvium from the older surfaces Q3m, Q4m, and Q5m on the upthrown side of the large, cumulative fault scarps, or due to the inability of surface clast dating to fully account for inheritance. Surfaces Q3m, Q4m, and Q5m yielded distinct, progressively older ages of $62.4 \pm 1.3,67.3 \pm 1.3$, and $78 \pm 1.5 \mathrm{ka}$, respectively (Table 1)

To demonstrate the extent to which the calculation of surface clast ages is affected by assigning erosion rates, we recalculate the ages and show the percentage error between the original clast ages ( $0 \mathrm{~mm} / \mathrm{ka}$ erosion rate) and the ages obtained by using reference erosion rates. We use both the $1 \mathrm{~mm} / \mathrm{ka}$ average depth profile estimate of erosion rates in this study and the $5 \mathrm{~mm} / \mathrm{ka}$ average bedrock and depth profile erosion rates also from the eastern flank of the eastern Argentine Precordillera (15km north of our study area) measured by Hedrick et al. (2013). Both aforementioned erosion rate values are consistent with the mean ${ }^{10} \mathrm{Be}$ global arid region bedrock erosion rates examined by Portenga and Bierman (2011). If we assume an erosion rate of $1 \mathrm{~mm} / \mathrm{ka}$, the ages of our Q2m and Q5m surfaces will be underestimated by up to $2 \%$ and $20 \%$ of the original ages, respectively. If we assume a higher erosion rate of $5 \mathrm{~mm} / \mathrm{ka}$, the ages of our Q2m and Q5m will be underestimated by up to $6 \%$ and $55 \%$ of the original ages, respectively. The ${ }^{36} \mathrm{Cl}$ surface clast ages (Table 1) should therefore be treated as minimum ages. However, erosion rates for sediments are usually higher than for cobble-sized surface clasts in arid regions (Placzek et al., 2014); consequently, erosion rates from depth profiles likely overestimate erosion rates of surface clasts.

\subsubsection{Displacement}

Topographic profiles of a series of cumulative scarps of the La Rinconada Fault which displace strath terraces have been utilized as markers to measure dip-slip displacement, shortening, and uplift through forward modelling of fault-fold geometries (Allmendinger, 1998). Initially, to produce simple reverse fault scarps with a gentle backlimb, the same P/S ratio, trishear apical angle, and initial fault tip position values were used and held constant throughout the model runs (see Table 3). We assume bedding plane slip that was initiated at the interface between the strath terrace and the basement rock and model the strath terrace as a line. Hence, we put the initial fault tip position at the surface. P/S ratio, which dictates the rate at which the fault tip

propagates compared to slip on the fault, was set as 1.0 , 
allowing the fault tip to propagate at the same rate that the fault is moving. Trishear apical angle was set as $50^{\circ}$.Trishear apical angle determines the distribution of strain above the fault tip; a low value results in concentration of intense strain in a narrow wedge of rock above the fault tip, while a high value results in diffuse strain (Allmendinger, 1998) in the material above the fault tip.

Fault-fold models with two hinges/inflection points which separate 3 ramps that become gradually shallower with depth were the best matches for the surveyed scarp profiles (Fig. 9). The dip of the fault at the surface was assumed to be $40^{\circ} \mathrm{E}$ in modeling of all four profiles based on measurement directly from an outcrop (Fig. 5A and 6). The dips of the two deeper ramps (Fig. 9), which were determined from iteratively modelling different fault parameter combinations, decrease gradually in dip. The hinge positions modelled for the different profiles were within $\sim 3 \mathrm{~m}$ of each other. On average these were found at depths of $\sim 45$ and $\sim 60 \mathrm{~m}$ from the footwall datum of $\mathrm{Q} 2 \mathrm{~m}$. The two deeper ramps had average dips of $\sim 33$ and $30^{\circ} \mathrm{E}$, respectively. The modelled position of the hinges and the dip of the ramps varied slightly among the profiles probably due to both usual along-strike irregularities in the fault plane geometry and varying degree of preservation of the strath terraces being fit to the modelled profiles. In the case of profile Q5m where backlimb folding is not as evident anymore, probably due to the more erosion it has undergone compared with the three younger terraces, matching of backlimb morphology was impossible. Matching of scarp height between the actual profile and modelled scarp profile was done instead. The hinge positions, ramp dips, and other trishear parameters (except for displacement) used in modelling Q3m were used for modelling a scarp of the same height as Q4m. The gentle $\left(\sim 10^{\circ}\right)$ backlimb inclination observed to east of the fault scarps (Fig. 9) can only be explained through this gradual decreasing fault dip with depth which resembles the fault-bend fold geometry of Suppe (1983). Significantly larger differences in successive fault dips, e.g., between a $40^{\circ} \mathrm{E}$ surface fault and a horizontal decollement, only results in steeper backlimb inclination.

Several other combinations of trishear parameters producing different scarp morphologies, exhibiting varying degrees of folding and amounts of surface rupture (see Figure S2), were used to explore the possible effect of assumed original scarp morphology on the amount of displacement measured. Original scarp morphology did not affect the modelled amount of displacement for faulted profiles at the $\mathrm{El}$ Molino site. This is most likely because the faulted profiles have distinct characteristics that limit the trishear parameter value combinations to those which result in the same displacement. For instance, because these scarps involve backlimb formation, and consequently require modelling fault bends, the initial fault tip point can only be modeled starting above the shallowest fault bend. The outcrop exposure showing bedrock material thrust over the Quaternary alluvium also helped in limiting possible original scarp morphologies. 
Although a lateral component of displacement cannot be precluded, only evidence of vertical displacement was observed and quantified at the El Molino site. Hence, only dip-slip displacement, shortening, and uplift measurements are presented. A trend of increasing cumulative displacement was observed on scarps cutting through progressively older strath terraces (Table 3). The amount of discrete displacement on each surface was measured by subtracting the dip-slip displacement of two consecutive terraces, e.g., Q3m and Q2m. Discrete displacement values were very large, with the lowest being $\sim 9 \mathrm{~m}$. The displacement modelled on the scarp cutting through Q2m is the true displacement since synchroneity of surface material on the upthrown side (Sample RS1) and downthrown surface (Sample RS6) can be argued from cosmogenic dating (Table 1). Displacement measured on surfaces Q3m, Q4m, and Q5m, most likely represent minimum estimates.

The $2.7 \mathrm{~m}$ of bedrock displacement measured from a trench exposure of the fault propagation fold scarp to the west of the main trace of the La Rinconada Fault (Fig.10A) is considered a minimum displacement since it only reflects offset along as single fault strand (fault strand 1) (Fig. 10A). The entire downthrown portion of the bedrock displaced by fault strand 2 (Fig. 10A) was not exposed due to time constraints. $4.2 \mathrm{~m}$ of displacement, on the other hand, was determined by forward modelling of a fault propagation fold (Fig. 9 and 10B).

\subsubsection{Slip rates}

Long-term average slip rates (Table 4) were computed for each cumulatively displaced strath terrace by dividing the amount of displacement by the age of the corresponding displaced strath terrace. For Q2m, the displacements measured on the cumulative scarp and the fault propagation fold were added and the depth profile age for Q2m was used since this more reliably accounts for inheritance (despite higher numerical uncertainty as compared to the surface sample age). The average dip-slip displacement rate, shortening rate, and uplift rate measured between surfaces Q2, Q3, Q4, and Q5 are $0.51 \pm 0.01,0.41 \pm 0.01$, and $0.34 \pm 0.01$ $\mathrm{mm} / \mathrm{yr}$, respectively. Long-term average slip showed a generally similar slip rate from Q5m-present (78 $\pm 1.5 \mathrm{ka})$ to Q2m-present $\quad\left(34.5^{-3.1} /+3.0 \mathrm{ka}\right)$ (Fig. 11). Slip rates were also computed for the relatively shorter intervals between formation of strath terraces and showed that rates apparently increased from the intervals Q4m-Q5m $(67.3 \pm 1.3$ to $78 \pm 1.5 \mathrm{ka})$ to $\mathrm{Q} 3 \mathrm{~m}-\mathrm{Q} 4 \mathrm{~m}(62.4 \pm 1.3$ to $67.3 \pm 1.3 \mathrm{ka})$ and decreased significantly in the interval Q2m-Q3m $\left(34.5^{-3.1} /+3.0\right.$ ka to $62.4 \pm 1.3 \mathrm{ka}$ ) (Table 4 and Fig. 12). Since displacement measured on scarps cutting through $Q 3 m, Q 4 m$, and Q5m are minimum estimates, calculated slip rates measured represent minimum estimates as well. Furthermore, slip rate uncertainty only reflects uncertainty in the ages and not of the shortening estimation method used. 


\subsection{Site 2: Arbol Quemado}

The Arbol Quemado Fault is a $\sim 1.5-\mathrm{km}$-long N-S trending minor fault strand $\sim 1 \mathrm{~km}$ to the east of the La Rinconada Fault and exhibits west-facing, counterslope reverse fault scarps. Similar to the main trace of the La Rinconada Fault, scarps are the result of bedding plane-slip. The bedding plane-fault, which dips $33^{\circ} \mathrm{E}$, lies within the eastern limb of what now appears to be an inactive anticline (Fig. 5B).

The scarps of the Arbol Quemado Fault reach as high as $\sim 5 \mathrm{~m}$. Similar to the El Molino site, the Arbol Quemado Fault displaces a series of strath terraces composed of late Quaternary alluvium and appears to reflect pure thrust faulting, due to the lack of evidence of laterally displaced terrace risers. A stream-cut sectional view of the scarp shows that the $33^{\circ} \mathrm{E}$-dipping fault dip follows the bedding orientation of the Loma de las Tapias Formation (Fig. 5B).

\subsubsection{Geomorphic Surfaces}

Prominent fault scarps that cut through multiple levels of extensive, well-preserved strath terraces are observed in the Arbol Quemado site. Seven levels of displaced strath terraces were identified (Q3a, Q4a, Q5a, Q6a, Q7a, Q8a, and Q9a), with the downthrown side of the strath terraces standing 12 to $19 \mathrm{~m}$ above the stream (Fig. 13). The intersection of terrace risers and upper terrace treads between successive terrace levels also served as piercing points for measurement of displacement in this area. The terraces have a regional dip of around $2-3^{\circ}$ to the east, $1-2^{\circ}$ to the south and unconformably overlie the Miocene Loma de las Tapias Formation.

The strath terrace deposits here share the same mixed lithology and most likely have the same clastic sources as the surfaces at the El Molino site. These surfaces also exhibit evidence of deflation and clasts which are imbricated to the east due to an east flowing stream. All of the seven strath terraces are composed of semi-rounded to semi-angular clasts. While clasts are expected to be more angular on surfaces that are higher (and older) due to the formation of desert pavement, the lack of marked differences in angularity could also be due to the impact of chemical weathering. Consequently, the only features indicative of relative age are sorting and desert varnish. The topographically lowest terrace (Q3a) is poorly sorted and has minimal desert varnish while the highest terrace (Q9a) is well sorted and has a significant fraction of clasts with desert varnish.

Most terraces (Q3a, Q4a, Q5a, Q6a, Q7a, Q8a, and Q9a) can be matched across the fault scarp, and unlike in the El Molino site, there is no correlation between the heights of strath terraces above the active stream and the amount of fault displacement on that particular terrace (see section 4.2.3 below). Both of these observations suggest that episodic downcutting, rather than abandonment due to hanging wall uplift, seems to be the main driving force of strath terrace formation in this site. 


\subsubsection{Ages}

Only the age of the topographically highest surface that was clearly displaced by the Arbol Quemado fault (Q9a) was determined for this site. Modelling of the depth profile samples in Arbol Quemado (Fig. 14) yields an age of $153.5^{-13.7} /+14.6 \mathrm{ka}$, an inheritance equivalent to $22.4^{-2.8 /}+2.7$ ka of prior exposure, and an erosion rate of 1.74 $\mathrm{mm} / \mathrm{ka}$. The shallowest sample (QD25) was excluded in the modelling of the depth profile age because of a very low concentration (see table 1). The low ${ }^{36} \mathrm{Cl}$ concentration is likely due to error in the wet chemistry sample preparation since the composition is similar to the deeper samples and because neither bioturbation nor reworking was observed in the top layer of sediment. The chronology of the rest of the surfaces in this locality were determined from relative dating, based both on their heights above the stream and their surface texture.

\subsubsection{Displacement}

Topographic profiles of a series of fault scarps which displace strath terraces in the Arbol Quemado site have been utilized as markers to measure dip-slip displacement, shortening, and uplift using the equations presented by Yang et al. (2015; Fig. 15). The equation used in this fault displacement measurement method (Yang et al., 2015) accounts for possible difference in slopes of the hanging wall and footwall surfaces. However, this method simplifies the measurement of displacement by assuming perfectly planar surfaces on each sides of the fault (Fig. 16). Dip-slip displacement, shortening, and uplift measurements are shown in Table 5.

The displacement measured along the scarps in Arbol Quemado are very similar for all the 7 terraces, ranging from $\sim 7-11 \mathrm{~m}$, with most values clustering around $\sim 7-9 \mathrm{~m}$. Unlike the scarps of the La Rinconada Fault in the El Molino site, the values do not show any trend of increasing displacement on older surfaces. The slight differences, including the higher displacement values for Q8a, could be due to the normal, alongstrike variation in displacement along faults. The average dip-slip displacement, shortening, and uplift values on all 7 surfaces are $8.51 \pm 0.61,7.13 \pm 0.51$, and $4.60 \pm 0.33 \mathrm{~m}$, respectively.

Due to the uncertainty in the original scarp morphology of the faulted profiles at the Arbol Quemado site, FFF modelling was also done to explore the possible range of displacement that can be measured from modelling several scarps with varying degrees of folding and amounts of surface rupture (see Figure S3). Variation in displacement among the different models was very limited and were still well within the range of displacement estimated from Yang et al.'s (2015) method. 


\subsubsection{Slip rates}

Displacement may have occurred any time after the formation of the Q3a surface, the youngest offset surface at the Arbol Quemado site. However, the only dated surface is Q9a, the oldest surface at the site. The age and displacement of Q9a yields a long-term average dip-slip displacement, shortening, and uplift rates of $0.050 \pm 0.002, \quad 0.045 \pm 0.002$, and $0.029 \pm 0.001 \mathrm{~mm} / \mathrm{yr}$, respectively. While the possibility of displacement occurring between Q9a and Q3a cannot be entirely ruled out, the consistency of displacement across all strath terraces strongly suggests either a single event or cumulative events which post-date formation of terrace Q3.

If a constant incision rate is assumed since formation of Q9a in the Arbol Quemado site,

an age of $~ 96.9 \pm 8.8$ ka can be projected for Q3a using the Q9a height above the river $(19 \mathrm{~m})$ and age $\left(153.5^{-13.7} /+14.6 \mathrm{ka}\right)$ and the Q3a height $(12 \mathrm{~m})$. The projected age and displacement of Q3a, yields similarly very low long-term average dip-slip displacement, shortening, and uplift rates of $0.08 \pm 0.016,0.06 \pm 0.014$, and $0.04 \pm 0.009 \mathrm{~mm} / \mathrm{yr}$, respectively.

Although our understanding of slip rate along the Arbol Quemado Fault would benefit from additional geochronology, which is beyond the scope of this study, we can confidently constrain a relatively low slip rate of $<0.1 \mathrm{~mm} / \mathrm{yr}$.

\section{Discussion}

\subsection{Late Quaternary Activity of the La Rinconada Fault Zone}

Several controversial, existing tectonic models have been proposed to explain surface faulting and heightened seismicity along the present-day Andean orogenic front in the region between the Precordillera and Sierras Pampeanas. These models vary in how they interpret the nature and geometry of structures at depth. Studies mainly along the southeast-dipping La Laja Fault, argue that the fault is the result of secondary flexural-slip or back thrusting (Costa et al., 1999) along an east-facing monocline within Neogene deposits (Meigs et al., 2006), which result from movement along a primary, west-dipping, blind thrust fault beneath the Eastern Precordillera. Meigs et al. (2006) argues that southeastward migration of backlimb fold hinges in the hanging wall of the La Laja Fault is caused by the emergence of the west-dipping blind thrust fault. Siame et al. (2002) also explain the rupture along the La Laja Fault through flexural slip, but by back-limb tightening linked to the Villicum-Pedernal Thrust on the west flank of the Eastern Precordillera. Richard et al. (2019) find no evidence from geologic mapping for a basement continuation of the LRF. Alternatively, Alvarado and Beck (2006) present seismological evidence which suggests that the La Laja Fault itself is a primary, east-dipping fault, associated with 
listric, basement-involved thrusts of the Sierras Pampeanas rather than the Precordillera. Alvarado and Beck (2006) supported their argument with earthquake parameters such as an earthquake a focal depth of $12 \mathrm{~km}$, a focal mechanism solution suggesting a fault plane with a NE-strike, SE-dip, a right-lateral sense of slip, and of $M_{W} 7.0$, all of which are consistent with the 1944 rupture being a primary fault.

Mapping of the La Rinconada Fault in this study shows that deformation is localized along the La Rinconada Fault, and to a minor degree, the Arbol Quemado Fault (Fig. 4). Although slip on the La Rinconada and Arbol Quemado faults occur along bedding planes of the Miocene Las Tapias Formation, there were no signs of widely-distributed slip along faults within several meters or tens of meters of either, which is what one would expect to observe if the faulting were related to flexuralslip. Furthermore, earthquake magnitude estimates from slip rates we measured, discussed in section 5.2, are larger than would be expected for a flexural-slip fault earthquake. The findings in this study, therefore, suggest that the La Rinconada Fault is a primary, east-dipping fault that possibly continues into the basement, similar to other east-dipping faults of the Sierras Pampeanas region, consistent with the findings of Alvarado and Beck (2006) for the La Laja Fault. However, further studies that will enable imaging the deeper structure of the LRFZ may help constrain the nature of this fault.

While our measurement of slip rate applies only over the last $78 \pm 1.5 \mathrm{ka}$, it appears that the relatively low relief across the La Rinconada Fault and lack of an associated large-scale geomorphic feature, i.e. a fault-bounded mountain range, may be in part due to its slow slip rate and a relatively recent initiation of movement along this fault.

The late Quaternary shortening rates measured on the La Rinconada Fault $(0.41 \pm 0.01 \mathrm{~mm} / \mathrm{yr})$ correspond to approximately $5-7 \%$ of the $5.5-7.7 \mathrm{~mm} / \mathrm{yr}$ longterm ( 20 Ma) geological shortening rates estimated for the entire width of the Principal Cordillera, Frontal Cordillera, and Precordillera from latitudes $30-33^{\circ} \mathrm{S}$ (Ramos et al., 2002, 2004; Zapata and Allmendinger, 1996). These rates correspond to $6-10 \%$ of the $2-7 \mathrm{~mm} / \mathrm{yr}$ ongoing shortening of the Andean Orogenic Front at the same range of latitudes based on GPS data by Kendrick et al. (1999, 2001, 2003, 2006) and $5-12 \%$ of the $4.5 \pm 1.7 \mathrm{~mm} / \mathrm{yr}$ determined by Brooks et al. (2003).

Our slip rate results for the La Rinconada Fault are a bit lower but on the same order of magnitude as slip rates determined for nearby faults in the Eastern Precordillera. Late Quaternary shortening rates measured on the Villicum-Las Tapias (Siame et al., 2002) and the La Laja faults (Rockwell et al., 2014) are 0.8 and $1.1 \mathrm{~mm} / \mathrm{yr}$, respectively. Siame et al. (2002) argue that this relatively low slip rate compared to the overall longer-term geological slip rates for the area can be explained by distribution of shortening across several thrusts across this latitude band $\left(31-32^{\circ} \mathrm{S}\right)$. 
To the south along the Precordillera, shortening rates are generally higher. Schoenbohm et al. (2013) measured rates of $0.59^{+0.10} /-0.13 \mathrm{~mm} / \mathrm{yr}$ for the central Las Peñas thrust and Schmidt et al. (2011) measured shortening rates of $1.2 \pm 0.2$ to $2.0 \pm 0.4 \mathrm{~mm} / \mathrm{yr}$ in the southern portion (Fig. 2). At latitude $33^{\circ} \mathrm{S}$, almost half of the regional shortening is taken up by the Las Peñas and Las Higueras Fault and the rest is distributed among fold-and-fault structures, while at the latitude of the La Cal Fault, about a quarter to a third of the shortening $(0.9 \pm 0.3$ to $1.5 \pm 0.3 \mathrm{~mm} / \mathrm{yr})$ is taken mostly by this structure alone (Schmidt et al., 2011). The relatively lower slip rates measured on the La Rinconada Fault, and other faults in the central Andean Orogenic Front, may be due to slip distribution among a larger number of faults and folds compared to the southern end. This pattern suggests more distributed deformation in the northern Precordillera in contrast to focusing of deformation on few structures in the southern Precordillera. We attribute this latitudinal change in strain distribution in the Precordillera to the pre-existing geology. A transition from NNE- to NNW-trending mountain ranges and active faults between the northern and southern Precordillera reflects a change in structural control of the Southern Precordillera by the pre-existing fabric and anisotropies of the Pampean crystalline basement (Ahumada and Costa, 2009; Costa et al., 2015b)

\subsection{Seismic Potential of the La Rinconada Fault Zone}

\subsubsection{La Rinconada Fault}

To assess the seismic potential of the La Rinconada Fault, we must make assumptions as to whether the terrace surfaces were abandoned coseismically, and whether the faults scarps are more likely the result of single or multiple events. As we cannot definitively support either scenario, we explore both, along with nonoffset-based methods to arrive at a seismic assessment of the fault.

At the El Molino site, it is uncertain whether all the terraces were consecutively coseismically uplifted. If the surfaces Q2m, Q3m, Q4m, and Q5m were uplifted by successive earthquakes, and we assume that the fault propagation fold is attributed to the most recent $1952 M_{W} 6.8$ San Juan earthquake, then this would imply the following earthquake recurrence intervals: $34.5^{-3.1} /+3.0 \mathrm{ka}$ (1952 A.D.-Q2a), $27.9 \pm 3.4$ (Q2a- Q3a), 4.9 $\pm 1.8(\mathrm{Q} 3 \mathrm{a}-\mathrm{Q} 4 \mathrm{a})$, and $11.2 \pm 2.0 \mathrm{ka}$ (Q4a-Q5a), with an average recurrence interval of $19.6 \pm 1.3 \mathrm{ka}$. There are unfortunately no independent constraints on timing and magnitude of past earthquakes on this fault, for instance, through paleoseismic trenching, to compare our findings with.

If the discrete displacements of each terrace (see Table 3 ) are taken as coseismic, earthquake magnitude can be estimated based on scaling relationships between earthquake magnitude and displacement (Wells and Coppersmith, 1994). The earthquake magnitudes estimated assuming that displacement measured can both 
represent either maximum displacement or average displacement ranges from $M_{W}$ 6.3-7.4. If, however, the terraces are not consecutively coseismically generated, displacement may reflect multiple events, and earthquake magnitude cannot be estimated using the methods of Wells and Coppersmith (1994).

Evidence to suggest the terraces are not consecutively coseismically generated comes from a model by Slemmons (1982) relating recurrence interval and earthquake magnitude to slip rate. According to this model, given the slip rates we measured (i.e., $0.41 \pm 0.01 \mathrm{~mm} / \mathrm{yr}$ ) and the average age difference of terraces (the implied average recurrence interval), the discrete displacement of the terraces would have had to be generated by $M_{W} 7.5$ to 8 earthquakes, which are much higher than the magnitudes estimated using discrete displacement.

Alternatively, earthquake magnitude for the La Rinconada Fault was also estimated using an equation relating magnitude to both slip rate and surface rupture length (Anderson et al., 1996; Anderson et al., 2017). A slip rate of $0.41 \pm 0.01 \mathrm{~mm} / \mathrm{yr}$ and a maximum surface rupture length of $30 \mathrm{~km}$ yielded an estimate ranging from $M_{W} 6.9$ to 7.2 .

It is worth noting that if we assume that the $4.2 \mathrm{~m}$ displacement on the fault propagation fold represents maximum displacement created by a single-event, this yields magnitude ranging from $M_{W} 6.6$ to 7.0 , which overlaps with the range of slip rate- derived magnitudes. While there is no documentation as to the ground rupture associated with the 1952 earthquake, the reported magnitude for the 1952 San Juan earthquake is very close to the range of possible earthquake magnitudes estimated for the La Rinconada Fault. The epicentral location of the 1952 earthquake $\left(31.6^{\circ} \mathrm{S}\right.$, $68.6^{\circ} \mathrm{W}$; INPRES, 1982) is also very close to the northern terminus of the La Rinconada Fault. These lines of evidence suggest that the La Rinconada Fault is a possible candidate for having generated the 1952 earthquake.

\subsubsection{Arbol Quemado Fault}

Similar uncertainty as to whether the Arbol Quemado Fault scarps are cumulative or single event hinder our analysis of this fault. On the basis of similarity in displacement of all 7 terraces, it is likely that the displacements measured correspond to a single event that occurred after the formation of the Q3a. Multiple events could have occurred either in between Q9a and Q3a or after the formation of Q3a, given the long duration of time of time in between Q9a and Q3a (56.6 \pm 16.5 ka) and Q3a-present $(96.9 \pm 8.8 \mathrm{ka})$. Due to this uncertainty, single-event and multiple-event scenarios are considered for the estimation of the seismogenic capability associated with the Arbol Quemado Fault.

Assuming that scarps represent single-event displacement, earthquake magnitude estimates for Arbol Quemado were computed by calculating the arithmetic mean of 
displacements measured from Q3a-Q9a and using the magnitude vs. average displacement scaling relationship equation of Wells and Coppersmith (1994) and Stirling et al. (2013). Using this equation, an average dip-slip displacement of $8.51 \pm 0.61 \mathrm{~m}$ corresponds to earthquake of $M_{W} 6.8 \pm 0.4$. Due to the uncertainty of number of events, this magnitude estimate should be treated with caution. Similar to the La Rinconada Fault, slip rate and fault length were also used to calculate earthquake size (Anderson et al., 1996; Anderson et al., 2017). Here, we use both slip rates from Q9a-present and Q3-present, yielding $M_{W}$ estimates of 6.0-6.2 and 5.9-6.3, respectively. These $M_{w}$ estimates are unsurprisingly significantly lower than magnitudes calculated the same way for the main La Rinconada fault trace of $M_{W}$ 6.9-7.2.

\section{Conclusions}

Average slip rates of the La Rinconada Fault Zone in Eastern Precordillera of Argentina determined from combined geomorphic, structural, and ${ }^{36} \mathrm{Cl}$ cosmogenic radionuclide data show an average shortening rate for $34.5^{-3.1} /+3.0 \mathrm{ka}$ to $78 \pm 1.5 \mathrm{ka}$ of $0.41 \pm 0.01 \mathrm{~mm} / \mathrm{yr}$. This geomorphically-derived shortening rate comprises $5-7 \%$ of the million-year geological timescale shortening rates for the entire width of the Principal Cordillera, Frontal Cordillera, and Precordillera and $5-12 \%$ of the decadal scale geodetic shortening rates for the Andean Orogenic Front. This relatively low shortening rate is comparable to shortening rates of other Andean Orogenic front reverse faults at similar range of latitudes $\left(31\right.$ to $\left.32^{\circ} \mathrm{S}\right)$ and can be explained through more widely distributed strain as suggested by Siame et al (2002) in his study of the Las Tapias Fault. The La Rinconada Fault Zone is capable of generating earthquakes with magnitudes ranging from $M_{W} 6.6$ to 7.2 that may potentially be destructive for the city of San Juan. Since the sequence of strath terraces that are cumulatively offset by the La Rinconada Fault are unlikely all coseismically displaced, timing and recurrence interval of surface-rupturing events associated with this fault will have to be determined independently associated with this fault.

\section{Acknowledgments}

This research was funded by a Natural Sciences and Engineering Research Council (NSERC) Discovery grant to Prof. Lindsay Schoenbohm (University of Toronto). The authors are grateful to $\mathrm{C}$. Distante for logistical and field assistance; Emilio Ahumada, Fabricio Vázquez, Héctor Cisneros, Irene Pérez and Mariana Coppolecchia for discussions and field assistance; and Sarah Hammer, Christopher Sheehan, and Paula Marques Figuereido for ${ }^{36} \mathrm{Cl}$ sample preparation assistance at the University of Cincinnati. The authors would also like to thank Instituto Nacional de Prevención Sísmica (INPRES) for securing permission for trench and cosmogenic pit excavation at the El Molino and Arbol Quemado sites. Many thanks to editor Nathan Niemi, and reviewers Fritz Schlunegger and Mike Taylor for their 
very constructive and useful comments. Examples of additional FFF modelling runs of different original scarp morphologies can be found in the supporting information.

\section{References}

Ahumada, E. A., \& Costa, C. H. (2009). Antithetic linkage between oblique Quaternary thrusts at the Andean front, Argentine Precordillera. Journal of South American Earth Sciences, 28(3), 207-216.

Allmendinger, R. W., Figueroa, D., Snyder, D., Beer, J., Mpodozis, C., \& Isacks, B. L. (1990). Foreland shortening and crustal balancing in the Andes at $30^{\circ} \mathrm{S}$ latitude. Tectonics, 9(4), 789-809.

Allmendinger, R. W., Jordan, T. E., Kay, S. M., \& Isacks, B. L. (1997). The evolution of the Altiplano-Puna plateau of the Central Andes. Annual Review of Earth and Planetary Sciences, 25(1), 139-174.

Allmendinger, R. W. (1998). Inverse and forward numerical modeling of trishear fault-propagation folds. Tectonics, 17(4), 640-656.

Allmendinger, R. W. and Shaw, J. H. (2000). Estimation of fault propagation distance from fold shape: Implications for earthquake hazard assessment. Geology, 28 (12), 1099-1102.

Allmendinger, R.W. and Judge, P.A. (2014). The Argentine Precordillera: A foreland thrust belt proximal to the subducted plate. Geosphere; 10 (6), 1203-1218.

Alvarado, P., \& Beck, S. (2006). Source characterization of the San Juan (Argentina) crustal earthquakes of 15 January $1944\left(M_{W} 7.0\right)$ and 11 June $1952\left(M_{W}\right.$ 6.8). Earth and Planetary Science Letters, 243(3), 615-631.

Ammirati, J. B., Luján, S. P., Alvarado, P., Beck, S., Rocher, S., \& Zandt, G. (2016). High-resolution images above the Pampean flat slab of Argentina $\left(31-32^{\circ} \mathrm{S}\right)$ from local receiver functions: Implications on regional tectonics. Earth and Planetary Science Letters, 450, 29-39.

Anderson, R. S., Repka, J. L., \& Dick, G. S. (1996). Explicit treatment of inheritance in dating depositional surfaces using in situ ${ }^{10} \mathrm{Be}$ and ${ }^{26} \mathrm{Al}$. Geology, $24(1), 47-51$.

Anderson, J. G., Wesnousky, S.G., and Stirling, M.W. (1996). Earthquake size as a function of fault slip rate. Bulletin of the Seismological Society of America, 86 (3), 683-690. 
Anderson, M., Alvarado, P., Zandt, G., \& Beck, S. (2007). Geometry and brittle deformation of the subducting Nazca Plate, Central Chile and Argentina. Geophysical Journal International, 171(1), 419-434.

Anderson, J. G., Biasi, G. P., \& Wesnousky, S. G. (2017). Fault-Scaling Relationships Depend on the Average Fault-Slip RateFault-Scaling Relationships Depend on the Average Fault-Slip Rate. Bulletin of the Seismological Society of America, 107(6), 2561-2577.

Armijo, R., Rauld, R., Thiele, R., Vargas, G., Campos, J., Lacassin, R., \& Kausel, E. (2010). The West Andean thrust, the San Ramon fault, and the seismic hazard for Santiago, Chile. Tectonics, 29(2).

Baby, P., Rochat, P., Mascle, G., \& Hérail, G. (1997). Neogene shortening contribution to crustal thickening in the back arc of the Central Andes. Geology, 25(10), 883-886.

Baldis, B. A., Beresi, M., Bordonaro, O., \& Vaca, A. (1982). Síntesis evolutiva de la Precordillera Argentina. In V Congreso Latinoamericano de Geología(Vol. 4, pp. 399-445).

Bastías, H. (1985). Fallamiento Cuaternario en la región sismotectónica de Precordillera (Doctoral dissertation, Tesis Doctoral. Facultad de Ciencias Exactas, Físicas y Naturales, Universidad Nacional de San Juan).

Bastías, H., Uliarte, E., Paredes, J., Sanchez, A., Bastias, J., Ruzycki, L., \& Perucca, L. (1990). Neotectónica de la 479 provincia de San Juan. In O. Bordonaro (Ed.), $11^{\circ}$ Congreso Geológico Argentino, Relatorio de Geología y Recursos Naturales de la Provincia de San Juan: San Juan, Argentina, Bordonaro, O.(Ed.), 228-245.

Blisniuk, K., Oskin, M., Fletcher, K., Rockwell, T., Sharp, W. (2012). Assessing the reliability of U-Series and $10 \mathrm{Be}$ dating techniques on alluvial fans in the Anza Borrego Desert, California. Quat. Geochronol. 13, 26-41.

Brooks, B., Bevis, M., Smalley, R., Kendrick, E., Manceda, R., \& Lauría, E. et al. (2003). Crustal motion in the Southern Andes $\left(26^{\circ}-36^{\circ} S\right)$ : Do the Andes behave like a microplate?. Geochemistry, Geophysics, Geosystems, 4(10),1-14.

Cahill, T. \& Isacks, B. (1992). Seismicity and shape of the subducted Nazca Plate. Journal of Geophysical Research, 97(B12), 17503-17529.

Cardozo, N., Bhalla, K., Zehnder, A. T., \& Allmendinger, R. W. (2003). Mechanical models of fault propagation folds and comparison to the trishear kinematic model. Journal of Structural Geology, 25(1), 1-18. 
Castellanos, A. (1944). El terremoto de San Juan. En Cuatro lecciones sobre terremotos, Asociación Cultural de Conferencias de Rosario, 79-242.

Castellanos, A. (1945). Cuatro Lecciones sobre terremotos. Parte B: El terremoto de San Juan: Asociación Cultural de Conferencias de Rosario, Publicación, 6, 77-243.

Cesta, J.M., Ward, D.J. (2016). Timing and nature of alluvial fan development along the Chajnantor Plateau, northern Chile. Geomorphology, 273, 412-427.

Cortés, J.M., Vinciguerra, P., Yamín, M. and Pasini, M.M. (1999) Tectónica cuaternaria

de la Región Andina del Nuevo Cuyo (28 $-38^{\circ}$ LS). En Geología Argentina. Servicio Geológico Minero Argentino, Subsecretaría de Minería, Buenos Aires.

Costa, C. H., \& Vita-Finzi, C. (1996). Late Holocene faulting in the southeast Sierras Pampeanas of Argentina. Geology, 24(12), 1127-1130.

Costa, C. (1999). Tectónica Cuaternaria en las Sierras Pampeanas. En Caminos, R. (ed.) Geología Argentina, SEGEMAR, Anales, 29, 779-784.

Costa, C., Machette, M. N., Dart, R., Bastías, H., Paredes, J. D., Perucca, L. P., Tello, G. E., \& Haller, K. M. (2000). Map and database of Quaternary faults and folds in Argentina. US Geological Survey Open-File Report, 108, 75.

Costa, C. H., Audemard, M., Bezerra, F. H. R., Lavenu, A., Machette, M. N., \& Paris, G. (2006). An overview of the main Quaternary deformation of South America. Revista de la Asociación Geológica Argentina, 61(4), 461-479.

Costa C. H., Ahumada E. A., Vázquez F. R. \& Kröhling D. M. (2015a). Holocene shortening rates of an Andean-front thrust, Southern Precordillera, Argentina. Tectonophysics, 664, 191-201.

Costa, C. H., Ahumada, E. A., Gardini, C. E., Vázquez, F. R., \& Diederix, H. (2015b). Quaternary shortening at the orogenic front of the Central Andes of Argentina: the Las Penas Thrust System. Geological Society, London, Special Publications, 399(1), 245-266.

Costa, C. H., Owen, L. A., Ricci, W. R., Johnson, W. J., \& Halperin, A. D. (2018). Holocene activity and seismogenic capability of intraplate thrusts: Insights from the Pampean Ranges, Argentina. Tectonophysics, 737, 57-70. 
Engdahl, E. R., van der Hilst, R., \& Buland, R. (1998). Global teleseismic earthquake relocation with improved travel times and procedures for depth determination. Bulletin of the Seismological Society of America, 88(3), 722-743.

Engdahl, E. R., \& Villaseñor, A. (2002). 41 Global seismicity: 1900-1999.

Erslev, E. A. (1991). Trishear fault-propagation folding. Geology, 19(6), 617-620.

Fielding, E. J., \& Jordan, T. E. (1988). Active deformation at the boundary between the Precordillera and Sierras Pampeanas, Argentina, and comparison with ancient Rocky Mountain deformation. Geological Society of America Memoirs, 171, 143-164.

Gosse, J. C., \& Phillips, F. M. (2001). Terrestrial in situ cosmogenic nuclides: theory and application. Quaternary Science Reviews, 20(14), 1475-1560.

Groeber, P. (1944). Movimientos tectónicos contemporáneos y un nuevo tipo de dislocaciones. Universidad Nacional de La Plata, Notas del Museo de La Plata, Geología 9, 263-375.

Gutscher, M. A., Spakman, W., Bijwaard, H., \& Engdahl, E. R. (2000). Geodynamics of flat subduction: seismicity and tomographic constraints from the Andean margin. Tectonics, 19(5), 814-833.

Hardy, S., \& Ford, M. (1997). Numerical modeling of trishear fault propagation folding. Tectonics, 16(5), 841-854.

Hardy, S., McClay, K. (1999). Kinematic modelling of extensional fault propagation folding. Journal of Structural Geology, 21, 695-702.

Hardy, S., Finch, E. (2007). Mechanical stratigraphy and the transition from trishear to kink-band fault-propagation folds formed above blind basement thrust faults: a discrete-element study. Marine and Petroleum Geology 24, 75-90.

Harrington, H. J. (1948). Volcanes y terremotos. Pleamar, 251.

Hedrick, K., Owen, L.A., Rockwell, T.K., Meigs, A., Costa, C., Caffee, M.W., Masana, E., Ahumada, E. (2013). Timing and nature of alluvial fan and strath terrace formation in the Eastern Precordillera of Argentina. Quat. Sci. Rev. 80, 143-168

Instituto Nacional de Prevencion Sismica (INPRES) (1977). Zonificacion Sismica de la Republica Argentina, Publ. Tec. 5, San Juan, Argentina. 
Instituto Nacional de Prevencion Sısmica (INPRES) (1982). Microzonificación sísmica del Valle de Tulum, provincia de San Juan: Resumen ejecutivo, San Juan, Argentina.

Isacks, B. L. (1988). Uplift of the central Andean plateau and bending of the Bolivian orocline. Journal of Geophysical Research: Solid Earth, 93(B4), 3211-3231.

Johnston, A. C. (1989). The seismicity of 'stable continental interiors. In Earthquakes at North-Atlantic Passive Margins: Neotectonics and Postglacial Rebound. Springer Netherlands, 299-327.

Jordán, T. E., Isacks, B. L., Allmendinger, R. W., Brewer, J. A., Ramos, V. A., \& Ando, C. J. (1983a). Andean tectonics related to geometry of subducted Nazca plate. Geological Society of America Bulletin, 94(3), 341-361.

Jordan, T. E., Isacks, B., Ramos, V. A., \& Allmendinger, R. W. (1983b). Mountain building in the Central Andes. Episodes, 557 3, 20-26.

Jordan, T. E., Allmendinger, R. W., Damanti, J. F., \& Drake, R. E. (1993). Chronology of motion in a complete thrust belt: the Precordillera, 30-31 S, Andes Mountains. The Journal of Geology, 101(2), 135-156.

Jordan, T. E., \& Allmendinger, R. W. (1986). The Sierras Pampeanas of Argentina: A modern analogue of Rocky Mountain foreland deformation. American Journal of Science, 286(10), 737-764.

Jordan, T. E., \& Gardeweg, M. (1989). Tectonic evolution of the late Cenozoic central Andes (20-33 S). The Evolution of the Pacific Ocean Margins, 193-207.

Johnson, K.M., Johnson, A.M. (2002). Mechanical analysis of the geometry of forced-folds. Journal of Structural Geology 24, 401-410.

Kadinsky-Cade, K., Reilinger, R., \& Isacks, B. (1985). Surface deformation associated with the November 23, 1977, Caucete, Argentina, earthquake sequence. Journal of Geophysical Research, 90(B14), 12691-12700.

Kendrick, E., Bevis,M., Smalley, R,. Cifuentes, O., \& Galban, F. (1999), Current rates of convergence across the Central Andes: Estimates from continuous GPS observations, Geophys. Res. Lett., 26, 541-544.

Kendrick, E., Bevis, M., Smalley, R., \& Brooks, B. (2001). An integrated crustal velocity field for the central Andes. Geochemistry, Geophysics, Geosystems, 2(11). 
Kendrick, E., Bevis, M., Smalley, R., Brooks, B., Vargas, R. B., Lauria, E., \& Fortes, L. P. S. (2003). The Nazca-South America Euler vector and its rate of change. Journal of South American Earth Sciences, 16(2), 125-131.

Kendrick, E., Brooks, B. A., Bevis, M., Smalley, R., Lauria, E., Araujo, M., \& Parra, H. (2006). Active orogeny of the South-Central Andes studied with GPS geodesy. Revista de la Asociación Geológica Argentina, 61(4), 555-566.

Kley, J., \& Monaldi, C. R. (1998). Tectonic shortening and crustal thickness in the Central Andes: How good is the correlation?. Geology, 26(8), 723-726.

Lal, D. (1988). In situ-produced cosmogenic isotopes in terrestrial rocks. Annual Review of Earth and Planetary Sciences, 16(1), 355-388.

Lal, D. (1991). Cosmic ray labeling of erosion surfaces: in situ nuclide production rates and erosion models. Earth and Planetary Science Letters, 104(2-4), 424-439.

Marrero, S.M., Phillips, F.M., Borchers, B., Lifton, N., Aumer, R., \& Balco, G. (2016). Cosmogenic nuclide systematics and the CRONUScalc program. Quat. Geochronol. 31, 160-187.

Martos, L. (1987). Evidencias de movimientos neotectónicos en una terraza de edad Holocena, la Rinconada. In San Juan: X Congreso Geologico Argentino Actas, 1, 263-265.

McFadden, L.D., Ritter, J.B., Wells, and S.G. (1989). Use of multiparameter relativeage methods for age estimation and correlation of alluvial fan surfaces on a desert piedmont, Eastern Mojave Desert, California. Quat. Res. 32 (3), 276-290.

Meigs, A., Krugh, W. C., Schiffman, C., Vergés, J., \& Ramos, V. A. (2006). Refolding of thin-skinned thrust sheets by active basement-involved thrust faults in the eastern Precordillera of western Argentina. Revista de la Asociación Geológica Argentina, 61(4), 589-603.

Moreno, C.A.M. (2013). "Neotectónica del Piedemonte de la Precordillera Oriental entre $31^{\circ} 51^{\prime} S$ - 31 55 'S, Provincia de San Juan." (Trabajo Final de Licenciatura. Facultad de Ciencias Físico Matemáticas y Naturales, Departamento de Geología, Universidad Nacional de San Luis).

Mulcahy, P., Chen, C., Kay, S. M., Brown, L. D., Isacks, B. L., Sandvol, E., Heit, B., Yuan, X., \& Coira, B. L. (2014). Central Andean mantle and crustal seismicity beneath the Southern Puna plateau and the northern margin of the ChileanPampean flat slab. Tectonics, 33(8), 1636-1658. 
Owen, L.A., Frankel, K.L., Knott, J.R., Reynhout, S., Finkel, R.C., Dolan, J.F., Lee, J. (2011). Beryl- lium-10 terrestrial cosmogenic nuclide surface exposure dating of Quaternary land- forms in Death Valley. Geomorphology 125 (4), 54-557.

Ortiz, A., \& Zambrano, J. J. (1981). La provincia geológica Precordillera oriental. In VIII Congreso Geológico Argentino, 3, 59-74.

Owen, L.A., Clemmens, S.J., Finkel, R.C., Gray, H., 2014. Late Quaternary alluvial fans at the eastern end of the San Bernardino Mountains, Southern California. Quat. Sci. Rev. 87, 114-134

Perg, L. A., Anderson, R. S., \& Finkel, R. C. (2001). Use of a new ${ }^{10} \mathrm{Be}$ and ${ }^{26} \mathrm{Al}$ inventory method to date marine terraces, Santa Cruz, California, USA. Geology, $29(10), 879-882$.

Perucca, L., \& Vargas, N. (2014). Neotectónica de la provincia de San Juan, centrooeste de Argentina. Boletín De La Sociedad Geológica Mexicana, 66(2), 291-304.

Phillips, F. M., Zreda, M. G., Smith, S. S., Elmore, D., Kubik, P. W., \& Sharma, P. (1990). Cosmogenic chlorine-36 chronology for glacial deposits at Bloody Canyon, eastern Sierra Nevada. Science, 248(4962), 1529.

Pilger, R. H. (1984). Cenozoic plate kinematics, subduction and magmatism: South American Andes. Journal of the Geological Society, 141(5), 793-802.

Placzek, C., Granger, D. E., Matmon, A., Quade, J., \& Ryb, U. (2014). Geomorphic process rates in the central Atacama Desert, Chile: insights from cosmogenic nuclides and implications for the onset of hyperaridity. American Journal of Science, 314(10), 1462-1512.

Portenga, E. W., \& Bierman, P. R. (2011). Understanding Earth's eroding surface with 10Be. GSA Today, 21(8), 4-10.

Proyecto Multinacional Andino (PMA): Geociencia para las Comunidades Andinas (2008). Atlas de deformaciones cuaternarias de los Andes. Servicio Nacional de Geología y Minería, Publicación Geológica Multinacional, 7, 1-320, 1 mapa en CDROM.

Ramos, V. A. (1988). The tectonics of the Central Andes; 30 to 33 S latitude. Geological Society of America Special Papers, 218, 31-54.

Ramos, V. (1999). Plate tectonic setting of the Andean Cordillera. Episodes, 22, 183190. 
Ramos, V. A., \& Kay, S. M. (1991). Triassic rifting and associated basalts in the Cuyo basin, central Argentina. Geological Society of America Special Papers, 265, 79-92.

Ramos, V. A., Cegarra, M., \& Cristallini, E. (1996). Cenozoic tectonics of the High Andes of west-central Argentina (30-36 ${ }^{\circ} S$ latitude). Tectonophysics, 259(1), 185200.

Ramos, V.A., Cegarra, M., Lo Forte, G. \& Cominguez, A. (1997). El frente orogénico en la Sierra de Pedernal (San Juan, Argentina): su migración a través de los depósitos orogénicos. 80 Congreso Geológico Chileno, Actas, 3, 1709-1713.

Ramos, V. A., Dallmeyer, R. D., \& Vujovich, G. (1998). Time constraints on the Early Palaeozoic docking of the Precordillera, central Argentina. Geological Society, London, Special Publications, 142(1), 143-158.

Ramos, V. A., Cristallini, E. O., \& Pérez, D. J. (2002). The Pampean flat-slab of the Central Andes. Journal of South American Earth Sciences, 15(1), 59-78.

Ramos, V.A., Zapata, T., and Cristallini, E.O., 2004, The Andean thrust system: Structural styles and orogenic shortening, in McClay, K.R., ed., Thrust Tectonics and Petroleum Systems: American Association of Petroleum Geologists Memoir 82.

Ramos, V. A., \& Folguera, A. (2009). Andean flat-slab subduction through time. Geological Society, London, Special Publications, 327(1), 31-54.

Ramos, V.A. \& Vujovich, G.I. (2000). Hoja Geológica 3169-IV, San Juan, Provincia de San Juan. Subsec. Minería Nación, Servicio Geológico Minero Argentino, Buenos Aires, Boletín 243, p. 82.

Repka, J. L., Anderson, R. S., \& Finkel, R. C. (1997). Cosmogenic dating of fluvial terraces, Fremont River, Utah. Earth and Planetary Science Letters, 152(1), 59-73.

Richard, A. D., Costa, C. H., Giambiagi, L. B., Moreno Marcó, C. A., Ahumada, E. A., \& Vázquez, F. R. (2019). Neotectónica del extremo austral de la Falla La Rinconada, Rrecordillera Oriental, Provincia de San Juan. Revista de la Asociación Geológica Argentina, 76(1).

Richard, A. D. (2013). "Neotectónica de la Precordillera Oriental entre $31^{\circ} 47^{\prime} 50$ " S 31'51'10" S, Provincia de San Juan." (Trabajo Final de Licenciatura. Facultad de Ciencias Físico Matemáticas y Naturales, Departamento de Geología, Universidad Nacional de San Luis). 
Riesner, M., Lacassin, R., Simoes, M., Carrizo, D., \& Armijo, R. (2018). Revisiting the crustal structure and kinematics of the Central Andes at $33.5^{\circ} \mathrm{S}$ : Implications for the mechanics of Andean mountain building. Tectonics, 37, 1347-1375.

Rockwell, T. K., Ragona, D. E., Meigs, A. J., Owen, L. A., Costa, C. H., \& Ahumada, E. A. (2014). Inferring a Thrust-Related Earthquake History from Secondary Faulting: A Long Rupture Record of La Laja Fault, San Juan, Argentina. Bulletin of the Seismological Society of America, 1, 269-284.

Salomon, E., Schmidt, S., Hetzel, R., Mingorance, F., \& Hampel, A. (2013). Repeated folding during late Holocene earthquakes on the La Cal thrust fault near Mendoza city (Argentina). Bulletin of the Seismological Society of America, 103(2A), 936-949.

Schmidt, S., Hetzel, R., Mingorance, F., \& Ramos, V. A. (2011). Coseismic displacements and Holocene slip rates for two active thrust faults at the mountain front of the Andean Precordillera ( $\left.33^{\circ} \mathrm{S}\right)$. Tectonics, 30(5).

Schoenbohm, L. M., Costa, C. H., Brooks, B. A., Bohon, W., Gardini, C., \& Cisneros, H. (2013, December). Fault interaction along the Central Andean thrust front: The Las Peñas thrust, Cerro Salinas thrust and the Montecito anticline. In AGU Fall Meeting Abstracts.

Siame, L. L., Bourlès, D. L., Sébrier, M., Bellier, O., Castano, J. C., Araujo, M., Perez, M., Raisbeck, G., \& Yiou, F. (1997). Cosmogenic dating ranging from 20 to $700 \mathrm{ka}$ of a series of alluvial fan surfaces affected by the El Tigre fault, Argentina. Geology, 25(11), 975-978.

Siame, L. L., Bellier, O., Sébrier, M., Bourlès, D. L., Leturmy, P., Perez, M., \& Araujo, M. (2002). Seismic hazard reappraisal from combined structural geology, geomorphology and cosmic ray exposure dating analyses: The Eastern Precordillera thrust system (NW Argentina). Geophysical Journal International, 150(1), 241-260.

Siame, L. L., Bellier, O., Sébrier, M., \& Araujo, M. (2005). Deformation partitioning in flat subduction setting: Case of the Andean foreland of western Argentina $\left(28^{\circ} \mathrm{S}-\right.$ $33^{\circ}$ S). Tectonics, 24(5).

Siame, L., Bellier, O., Sébrier, M. (2006). Active tectonics in the Argentine Precordillera and Western Sierras Pampeanas, Rev. Asoc. Geol. Arg., 61 (4), 604619.

Siame, L. L., Sébrier, M., Bellier, O., Bourlès, D., Costa, C., Ahumada, E. A., Gardini, C., \& Cisneros, H. (2015). Active basement uplift of Sierra Pie de Palo (Northwestern 
Argentina): Rates and inception from ${ }^{10} \mathrm{Be}$ cosmogenic nuclide concentrations. Tectonics, 34(6), 1129-1153.

Slemmons, D. B. (1982). Determination of design earthquake magnitudes for microzonation, Proc. of the Third International Earthquake Microzonation Conf. Vol. 1, U.S. National Science Foundation, Washington, D.C., 119-130.

Smalley, R., \& Isacks, B. L. (1990). Seismotectonics of thin-and thick-skinned deformation in the Andean Foreland from local network data: Evidence for a seismogenic lower crust. Journal of Geophysical Research: Solid Earth, 95(B8), 12487-12498.

Smalley, R., Pujol, J., Regnier, M., Chiu, J. M., Chatelain, J. L., Isacks, B. L., Araujo, M., Puebla, N. (1993). Basement seismicity beneath the Andean Precordillera thinskinned thrust belt and implications for crustal and lithospheric behavior. Tectonics, 12(1), 63-76.

Stirling, M., Goded, T., Berryman, K., \& Litchfield, N. (2013). Selection of earthquake scaling relationships for seismic-hazard analysis. Bulletin of the Seismological Society of America, 103(6), 2993-3011.

Stone, J. O. H., Evans, J. M., Fifield, L. K., Allan, G. L., \& Cresswell, R. G. (1998). Cosmogenic chlorine-36 production in calcite by muons. Geochimica et Cosmochimica Acta, 62(3), 433-454.

Stone J. (2000). Air pressure and cosmogenic isotope production. J. Geophys. Res. 105: 23753-23759.

Stone, J., Evans, J., Field, K., Cresswell, R., Allan, G. (1996). Cosmogenic chlorine36 production rates from calcium and potassium. Radiocarbon 38 (1), 170-171.

Suppe, J., Geometry and kinematics of fault bend folding, Am. J. Sci., 283, 684-721, 1983.

Tello, G. and Perucca, L. (1993). The Precordillera Oriental fault system and its relation to the historic earthquakes of 1944 and 1952, San Juan, Argentina, in the Twelfth Argentine Geological Congress: Mendoza, Argentina, Asociación Geológica Argentina, 258-265.

Uliarte, E., Bastías, H., \& Ruzycki, L. (1987). Morfología y neotectónica en el Cerro La Chilca, Pedernal, Provincia de San Juan, Argentina. 10 Congr Geol Argent Tucuman, Actas, 1, 227-230. 
Vázquez, F. R., C. H. Costa, and C. E. Gardini (2016), Quaternary-active thrusts scarps tested as deformation markers by trishear models in the Southern Precordillera of Argentina, Quat. Int.

Vergés, J., Ramos, V. A., Meigs, A., Cristallini, E., Bettini, F. H., \& Cortés, J. M. (2007). Crustal wedging triggering recent deformation in the Andean thrust front between $31^{\circ} \mathrm{S}$ and $33^{\circ} \mathrm{S}$ : Sierras Pampeanas-Precordillera interaction. Journal of Geophysical Research: Solid Earth, 112(B3).

Volponi, F., Quiroga, M., Robles, A., \& Sisterna, J. (1984). El terremoto de Caucete del 23 de noviembre de 1977. Instituto Sismológico Zonda, FCEFyN, Universidad Nacional de San Juan, San Juan.

Von Gosen, W. (1992). Structural evolution of the Argentine precordillera: the Rio San Juan section. Journal of Structural Geology, 14(6), 643-667.

Yang, X., Li, W., \& Qin, Z. (2015). Calculation of reverse-fault-related parameters using topographic profiles and fault bedding. Geodesy and Geodynamics, 6(2), 106112.

Yeats, R. (2015). Earthquake Time Bombs. Cambridge University Press.

Zapata, T. R., \& Allmendinger, R. W. (1996). Thrust-front zone of the Precordillera, Argentina: a thick-skinned triangle zone. AAPG bulletin, 80(3), 359-381.

Zehnder, A. T., \& Allmendinger, R. W. (2000). Velocity field for the trishear model. Journal of Structural Geology, 22(8), 1009-1014. 
Table 1. $36 \mathrm{Cl}$ surface and depth profile sample data and ages from strath terraces offset by cumulative scarps of the La Rinconada Fault and Arbol Quemado Fault.

\begin{tabular}{|c|c|c|c|c|c|c|c|c|c|c|c|c|}
\hline Sample no. & Surface & $\begin{array}{l}\text { Latitude } \\
\left({ }^{\circ} \mathrm{S}\right)\end{array}$ & $\begin{array}{l}\text { Longitude } \\
\qquad\left({ }^{\circ} \mathrm{W}\right)\end{array}$ & $\begin{array}{l}\text { Elevation } \\
(\mathrm{m})\end{array}$ & Material $^{\mathrm{a}}$ & $\begin{array}{c}\text { Thickness } \\
(\mathrm{cm})\end{array}$ & $\begin{array}{l}\text { Topographic } \\
\text { Shielding }\end{array}$ & $\begin{array}{c}\text { Cl Rock } \\
\text { (ppm) }\end{array}$ & $\begin{array}{c}36 \mathrm{Cl} / \mathrm{Cl} \\
\left(10^{-15}\right)\end{array}$ & $\begin{array}{c}36 \mathrm{Cl} \\
\text { Concentration } \\
\left(10^{6} \text { at g }^{-1}\right)\end{array}$ & $\begin{array}{c}\text { Normalized } \\
\text { Concentration } \\
\left(10^{6} \text { at g }^{-1}\right)^{\mathrm{b}}\end{array}$ & $\begin{array}{l}\text { Exposure age } \\
(k a)^{c, d}\end{array}$ \\
\hline \multicolumn{13}{|c|}{ Surface Samples } \\
\hline $\mathrm{RS} 1$ & Q2m & 31.72481 & 291.38925 & 782 & $\mathrm{~L}$ & 2.5 & 0.9985 & $15.19 \pm 0.31$ & $1805.18 \pm 27.44$ & $1.7342 \pm 0.0279$ & & $36.9 \pm 0.8$ \\
\hline RS2 & Q3m & 31.72393 & 291.39178 & 777 & $\mathrm{~L}$ & 2.5 & 0.9985 & $21.01 \pm 0.21$ & $2371.54 \pm 35.84$ & $2.5457 \pm 0.0393$ & & $62.4 \pm 1.3$ \\
\hline RS3 & $\mathrm{Q} 4 \mathrm{~m}$ & 31.72400 & 291.38788 & 788 & L & 2.5 & 0.9985 & $17.11 \pm 0.16$ & $2658.8 \pm 35.66$ & $2.7051 \pm 0.0368$ & & $67.3 \pm 1.3$ \\
\hline RS4 & Q5m & 31.72284 & 291.38837 & 785 & L & 2.5 & 0.9985 & $16.33 \pm 0.16$ & $2948.1 \pm 39.51$ & $3.0105 \pm 0.0409$ & & $78 \pm 1.5$ \\
\hline RS6 & $\mathrm{Q} 2 \mathrm{~m}$ & 31.72540 & 291.38690 & 787 & $\mathrm{~L}$ & 2.5 & 0.9985 & $14.64 \pm 0.22$ & $1637.09 \pm 24.84$ & $1.9069 \pm 0.0295$ & & $41.4 \pm 0.9$ \\
\hline \multicolumn{13}{|c|}{ Channel Samples } \\
\hline RS5 & QOm & 31.72530 & 291.38770 & 779 & L & 2.5 & 0.9905 & $13.55 \pm 0.39$ & $495.07 \pm 7.98$ & $0.5109 \pm 0.0089$ & & - \\
\hline \multicolumn{13}{|l|}{ Depth Profiles } \\
\hline RD25 & $\mathrm{Q} 2 \mathrm{~m}$ & 31.72481 & 291.38925 & 782 & L\&S & 0.5 & 0.9985 & $30.61 \pm 0.19$ & $650.89 \pm 11.94$ & $0.8894 \pm 0.0166$ & 0.9836 & $34.531 .4-37.5$ \\
\hline RD50 & & 31.72481 & 291.38925 & 782 & L\&S & 0.5 & 0.9985 & - & $22.33 \pm 1.14$ & - & - & \\
\hline RD75 & & 31.72481 & 291.38925 & 782 & L\&S & 0.5 & 0.9985 & $27.39 \pm 0.20$ & $651.73 \pm 10.43$ & $0.7789 \pm 0.0127$ & 0.7273 & \\
\hline RD150 & & 31.72481 & 291.38925 & 782 & L\&S & 0.5 & 0.9985 & $35.18 \pm 0.30$ & $448.75 \pm 7.98$ & $0.5697 \pm 0.0105$ & 0.5671 & \\
\hline QD25 & Q9a & 31.83996 & 291.40618 & 742 & L\&S & 0.5 & 0.9999 & $32.51 \pm 0.24$ & $866.93 \pm 12.74$ & $1.1202 \pm 0.0169$ & - & $153.5139 .8-168.1$ \\
\hline QD50 & & 31.83996 & 291.40618 & 742 & L\&S & 0.5 & 0.9999 & $54.33 \pm 0.39$ & $729.6 \pm 11.05$ & $1.4974 \pm 0.0234$ & 1.3550 & \\
\hline QD75 & & 31.83996 & 291.40618 & 742 & L\&S & 0.5 & 0.9999 & $36.62 \pm 0.47$ & $670.81 \pm 9.58$ & $0.8913 \pm 0.0139$ & 0.8842 & \\
\hline QD100 & & 31.83996 & 291.40618 & 742 & L\&S & 0.5 & 0.9999 & $37.57 \pm 0.38$ & $521 \pm 9.00$ & $0.7071 \pm 0.0128$ & 0.7389 & \\
\hline QD150 & & 31.83996 & 291.40618 & 742 & L\&S & 0.5 & 0.9999 & $31.03 \pm 0.51$ & $428.56 \pm 9.25$ & $0.5209 \pm 0.012$ & 0.5666 & \\
\hline
\end{tabular}

- Indicates no data or not applicable.

${ }^{a}$ L= Limestone; L\&S = Limestone and Shale mix.

${ }^{\mathrm{b}}$ Normalization of concentration values to average depth profile chemical composition is done for better visualization of best-fit solutions. 
${ }^{c}$ For surface samples, inheritance correction was done by subtracting concentration of channel sample RS5 first before computing ages.

${ }^{d}$ For depth profiles, Bayesian most probable solution (bold) and $95 \%$ confidence level upper and lower age range.

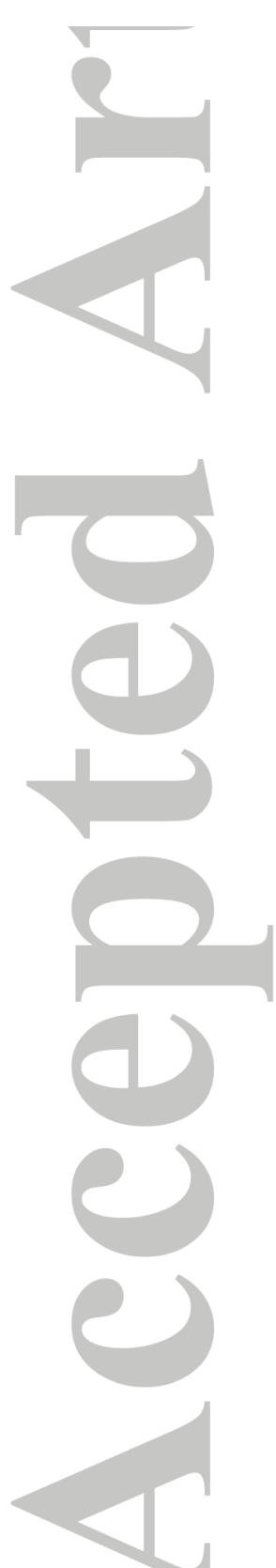


Table 2. Geochemical and isotopic analytical data for surface and depth profile samples gathered from both El Molino and Arbol Quemado sites.

\begin{tabular}{|c|c|c|c|c|c|c|c|c|c|c|c|c|c|c|c|c|c|c|}
\hline Sample no. & $\begin{array}{c}\mathrm{SiO}_{2} \text { (wt. } \\
\% \text { ) }\end{array}$ & $\begin{array}{c}\mathrm{TiO}_{2} \\
\text { (wt. \%) }\end{array}$ & $\begin{array}{l}\mathrm{Al}_{2} \mathrm{O}_{3} \\
\text { (wt. \%) }\end{array}$ & $\begin{array}{l}\mathrm{Fe}_{2} \mathrm{O}_{3} \\
\text { (wt. \%) }\end{array}$ & $\begin{array}{c}\mathrm{MnO} \\
\text { (wt. \%) }\end{array}$ & $\begin{array}{c}\mathrm{MgO} \\
\text { (wt. \%) }\end{array}$ & $\begin{array}{c}\mathrm{CaO} \\
\text { (wt. \%) }\end{array}$ & $\begin{array}{c}\mathrm{Na}_{2} \mathrm{O} \\
\text { (wt. \%) }\end{array}$ & $\begin{array}{c}\mathrm{K}_{2} \mathrm{O} \\
\text { (wt. } \\
\% \text { ) }\end{array}$ & $\begin{array}{c}\mathrm{P}_{2} \mathrm{O}_{5} \\
\text { (wt. \%) }\end{array}$ & $\begin{array}{c}\mathrm{CO}_{2} \\
\text { (wt. \%) }\end{array}$ & $\begin{array}{c}\mathrm{H}_{2} \mathrm{O} \\
\text { (wt. \%) }\end{array}$ & $\begin{array}{c}\text { B } \\
(\mathrm{ppm})\end{array}$ & $\begin{array}{c}\mathrm{Sm} \\
\text { (ppm) }\end{array}$ & $\begin{array}{c}\text { Gd } \\
\text { (ppm) }\end{array}$ & $\begin{array}{c}U \\
(\mathrm{ppm})\end{array}$ & $\begin{array}{c}\text { Th } \\
\text { (ppm) }\end{array}$ & $\begin{array}{c}\mathrm{Cr} \\
\text { (ppm) }\end{array}$ \\
\hline \multicolumn{19}{|c|}{ Surface Samples } \\
\hline RS1 & 1.11 & $<0.01$ & 0.07 & 0.07 & $<0.01$ & 1.35 & 53.84 & $<0.01$ & 0.04 & $<0.01$ & 21.70 & 21.70 & $<3$ & 0.08 & 0.14 & 0.6 & $<0.2$ & $<0.14$ \\
\hline RS2 & 2.53 & $<0.01$ & 0.17 & 0.13 & $<0.01$ & 0.59 & 53.43 & $<0.01$ & 0.06 & $<0.01$ & 21.50 & 21.50 & $<3$ & 0.28 & 0.31 & 1.3 & 0.3 & $<0.14$ \\
\hline RS3 & 2.60 & 0.02 & 0.23 & 0.16 & $<0.01$ & 0.67 & 53.39 & $<0.01$ & 0.08 & $<0.01$ & 21.40 & 21.40 & 6 & 0.24 & 0.28 & 0.9 & 0.3 & $<0.14$ \\
\hline RS4 & 2.15 & $<0.01$ & 0.18 & 0.12 & $<0.01$ & 0.66 & 53.45 & $<0.01$ & 0.07 & $<0.01$ & 21.65 & 21.65 & 7 & 0.24 & 0.28 & 0.9 & 0.2 & $<0.14$ \\
\hline RS6 & 2.12 & 0.01 & 0.12 & 0.09 & $<0.01$ & 0.48 & 54.13 & $<0.01$ & 0.05 & $<0.01$ & 21.45 & 21.45 & $<3$ & 0.18 & 0.19 & 1.1 & $<0.2$ & $<0.14$ \\
\hline \multicolumn{19}{|c|}{ Channel Samples } \\
\hline RS5 & 1.75 & $<0.01$ & 0.17 & 0.13 & $<0.01$ & 1.7 & 52.87 & $<0.01$ & 0.07 & $<0.01$ & 21.60 & 21.60 & 10 & 0.21 & 0.24 & 0.9 & 0.2 & $<0.14$ \\
\hline \multicolumn{19}{|l|}{ Depth Profiles } \\
\hline RD25 & 41.82 & 0.55 & 10.42 & 4.92 & 0.06 & 2.16 & 18.72 & 1.15 & 2.24 & 0.12 & 8.85 & 8.85 & 37 & 5.2 & 4.59 & 2.8 & 7.9 & 0.62 \\
\hline RD50 & 33.18 & 0.43 & 8.1 & 3.81 & 0.06 & 2.07 & 27.31 & 0.87 & 1.77 & 0.09 & 11.10 & 11.10 & 30 & 3.8 & 3.63 & 2 & 5.9 & 0.75 \\
\hline RD75 & 33.69 & 0.45 & 8.52 & 3.94 & 0.05 & 2.16 & 25.59 & 0.90 & 1.86 & 0.09 & 11.30 & 11.30 & 27 & 3.79 & 3.62 & 2.2 & 6.3 & 0.48 \\
\hline RD150 & 37.98 & 0.5 & 9.53 & 4.49 & 0.06 & 2.2 & 21.81 & 1.00 & 2.09 & 0.10 & 10.05 & 10.05 & 33 & 4.46 & 4.22 & 2.3 & 6.8 & 0.55 \\
\hline QD25 & 38.67 & 0.29 & 4.84 & 2.86 & 0.05 & 2.61 & 20.36 & 0.83 & 0.81 & 0.07 & 8.55 & 8.55 & 15 & 2.53 & 2.74 & 2.3 & 3.5 & 0.89 \\
\hline QD50 & 46.97 & 0.36 & 6.22 & 3.59 & 0.06 & 2.87 & 20.10 & 0.97 & 1.08 & 0.08 & 8.75 & 8.75 & 21 & 3.32 & 3.51 & 2.3 & 4.2 & 1.03 \\
\hline QD75 & 45.53 & 0.35 & 6.14 & 3.6 & 0.06 & 2.84 & 20.60 & 0.95 & 1.09 & 0.08 & 9.30 & 9.30 & 23 & 3.28 & 3.44 & 2.7 & 4.5 & 1.23 \\
\hline QD100 & 47.16 & 0.36 & 6.34 & 3.82 & 0.07 & 2.93 & 18.76 & 0.96 & 1.13 & 0.08 & 9.10 & 9.10 & 22 & 3.58 & 3.58 & 2.2 & 4.5 & 3.35 \\
\hline QD150 & 47.61 & 0.36 & 6.42 & 3.56 & 0.07 & 2.72 & 18.77 & 0.98 & 1.13 & 0.09 & 9.05 & 9.05 & 22 & 3.45 & 3.5 & 2.3 & 4.5 & 2.05 \\
\hline
\end{tabular}

${ }^{\mathrm{a}}$ Elemental Concentrations from $\mathrm{Na}_{2} \mathrm{O}_{2}$ Fusion and ICP-MS of whole sediment measured at Bureau Veritas Commodities Canada Ltd., British Columbia.

Uncertainties are taken to be \pm 0.01 for all major oxides, \pm 0.10 for all trace elements, and \pm 0.5 for Boron. 
Table 3. Dip-slip displacement, shortening, and uplift calculated from the scarps of the La Rinconada Fault at the El Molino site.

\begin{tabular}{|c|c|c|c|c|c|c|c|c|c|c|}
\hline \multirow[b]{2}{*}{ Surface $^{a}$} & \multirow[b]{2}{*}{ Ramp } & \multirow{2}{*}{$\begin{array}{l}\text { Apical } \\
\text { Angle }\end{array}$} & \multirow{2}{*}{$\begin{array}{l}\mathrm{P} / \mathrm{S} \\
\text { Ratio }\end{array}$} & \multirow{2}{*}{$\begin{array}{c}\text { Tip } \\
\text { point } \\
\text { position }\end{array}$} & \multicolumn{3}{|c|}{ Cumulative $^{\mathrm{b}}$} & \multicolumn{3}{|c|}{ Discrete $^{b}$} \\
\hline & & & & & $\begin{array}{c}\text { Dip-slip } \\
\text { displacement } \\
\text { (m) }\end{array}$ & $\begin{array}{l}\text { Shortening } \\
(\mathrm{m})\end{array}$ & $\begin{array}{l}\text { Uplift } \\
\text { (m) }\end{array}$ & $\begin{array}{c}\text { Dip-slip } \\
\text { displacement } \\
\text { (m) }\end{array}$ & $\begin{array}{l}\text { Shortening } \\
(\mathrm{m})\end{array}$ & $\begin{array}{l}\text { Uplift } \\
\text { (m) }\end{array}$ \\
\hline Q2m (FPF) & 40 & 15 & 2.5 & $-5.2 \mathrm{~m}$ & \multirow{2}{*}{20.76} & \multirow{2}{*}{15.90} & \multirow{2}{*}{13.34} & 4.2 & 3.22 & 2.7 \\
\hline Q2m (main) & 40 & 50 & 1 & Surface & & & & 16.56 & 12.69 & 10.54 \\
\hline Q3m & 40 & 50 & 1 & Surface & 25.23 & 19.33 & 16.22 & 4.47 & 3.43 & 2.88 \\
\hline $\mathrm{Q} 4 \mathrm{~m}$ & 40 & 50 & 1 & Surface & 34.48 & 26.41 & 22.16 & 9.25 & 7.08 & 5.94 \\
\hline $\mathrm{Q} 5 \mathrm{~m}$ & 40 & 50 & 1 & Surface & 49.5 & 37.92 & 31.82 & 15.02 & 11.51 & 9.66 \\
\hline
\end{tabular}

${ }^{a}$ The main scarp and the fault propagation fold (FPF) displacements on Q2m are distinguished.

${ }^{b}$ Both cumulative displacement and terrace-specific displacement values are presented for each terrace. 
Table 4. Dip-slip, shortening, and uplift rates calculated from the cumulative scarps of the La Rinconada Fault at the El Molino site.

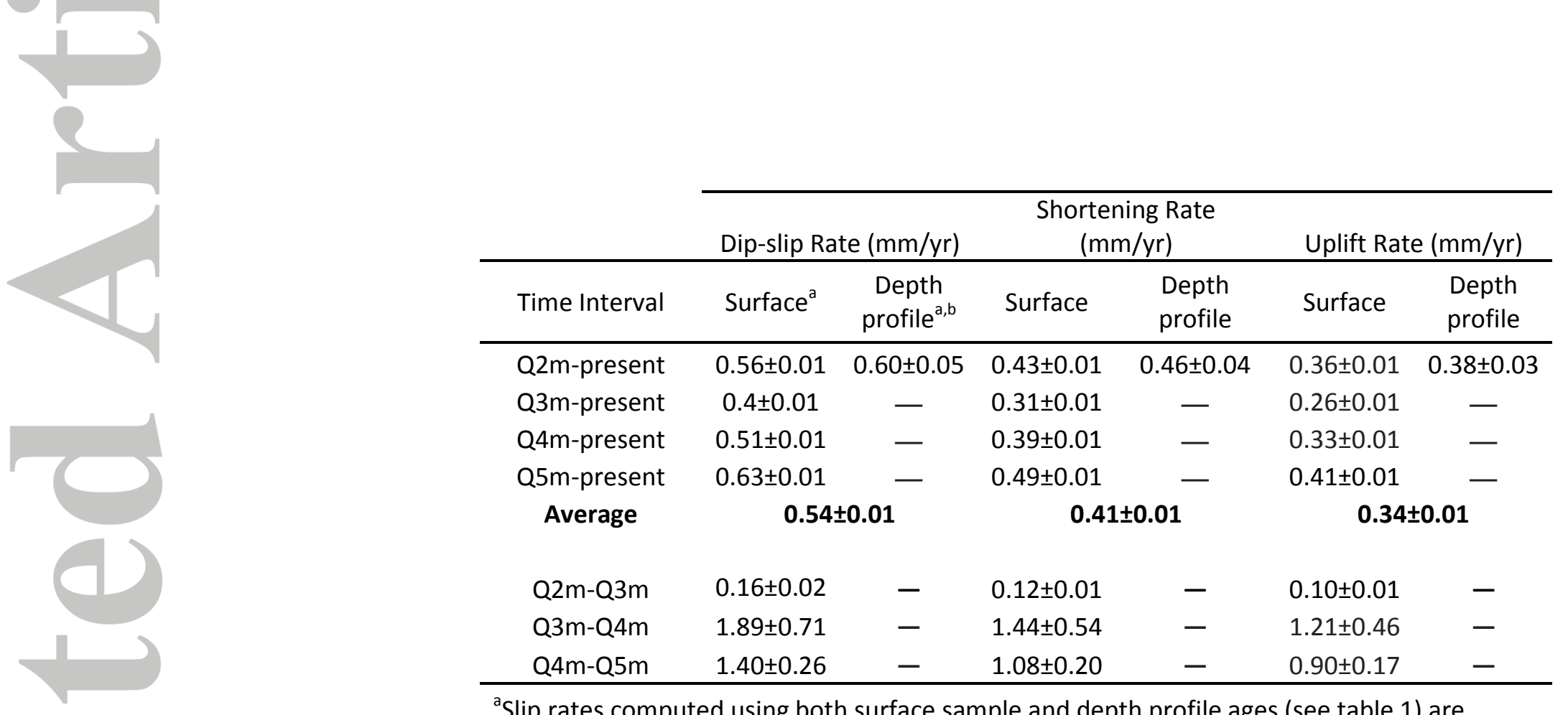

${ }^{\text {a}}$ Slip rates computed using both surface sample and depth profile ages (see table 1 ) are shown. ${ }^{b} \mathrm{Q} 2 \mathrm{~m}$ - present' depth profile slip rates were used to compute average slip rates . 
Table 5. Dip-slip displacement, shortening, and uplift calculated from scarps of the Arbol Quemado Fault.

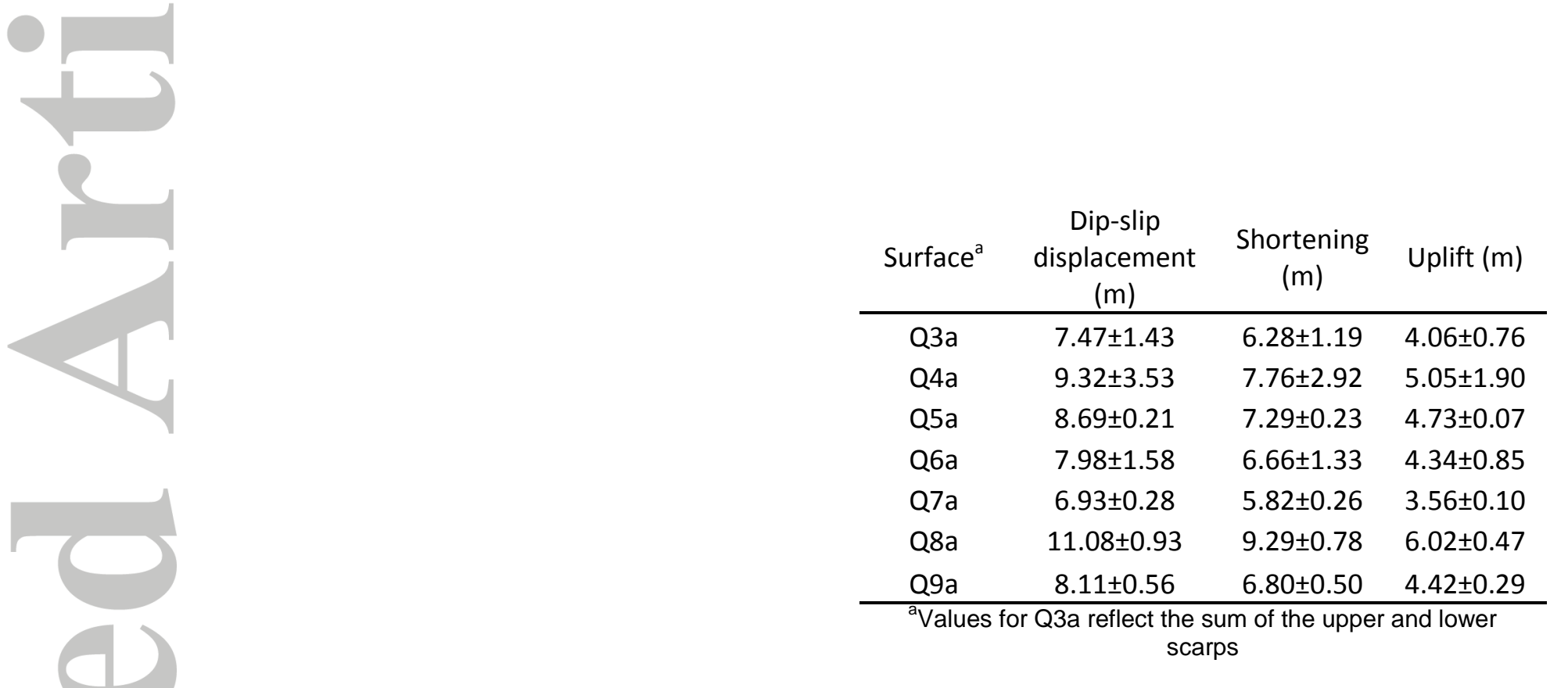




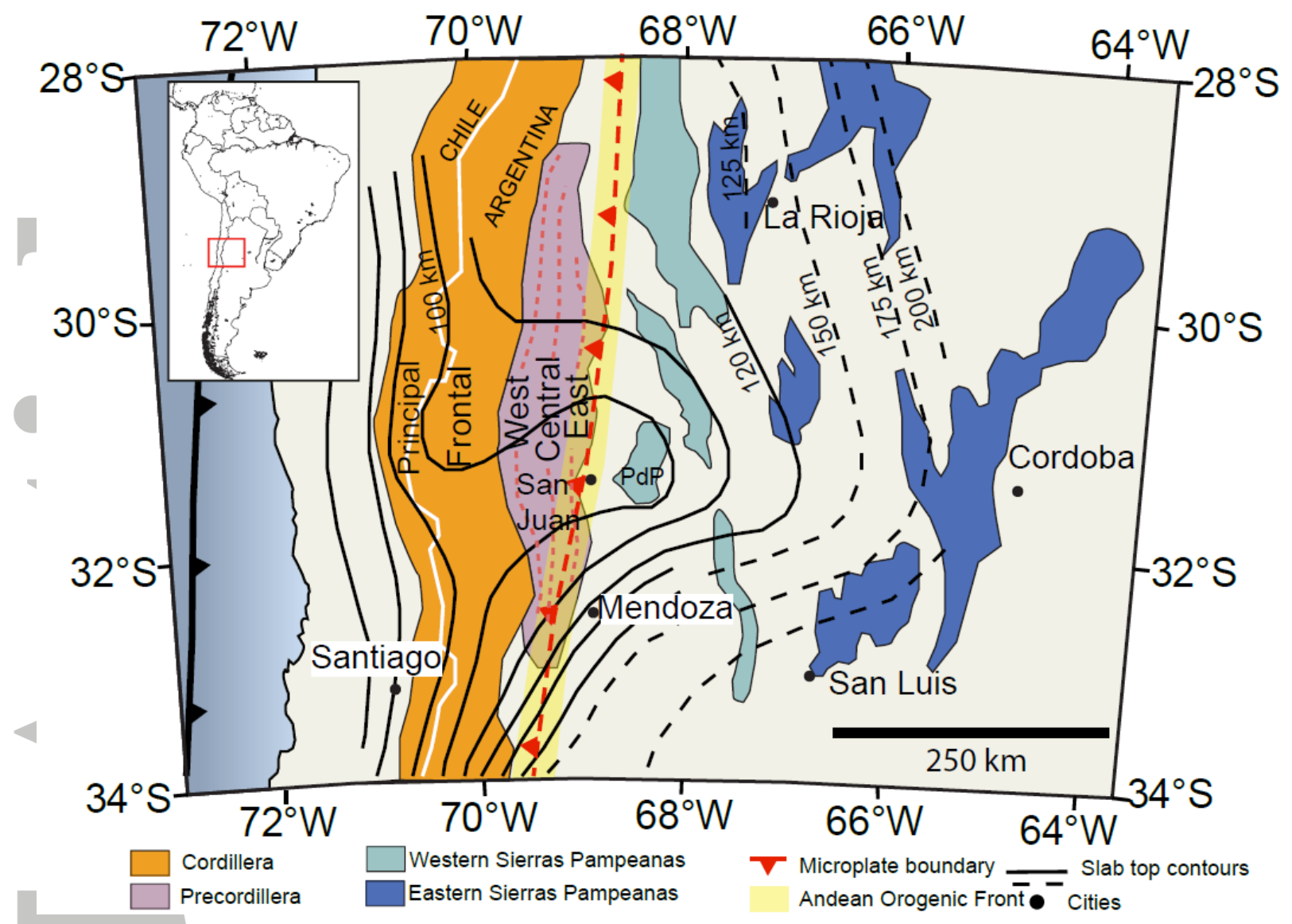

Figure 1. Location map centered on the Pampean flat slab segment. Slab top contours are represented by thin black lines (Anderson et al., 2007) and thin black dashed lines (Mulcahy et al., 2014). PdP stands for Pie de Palo in the western Sierras Pampeanas tectonic block. 


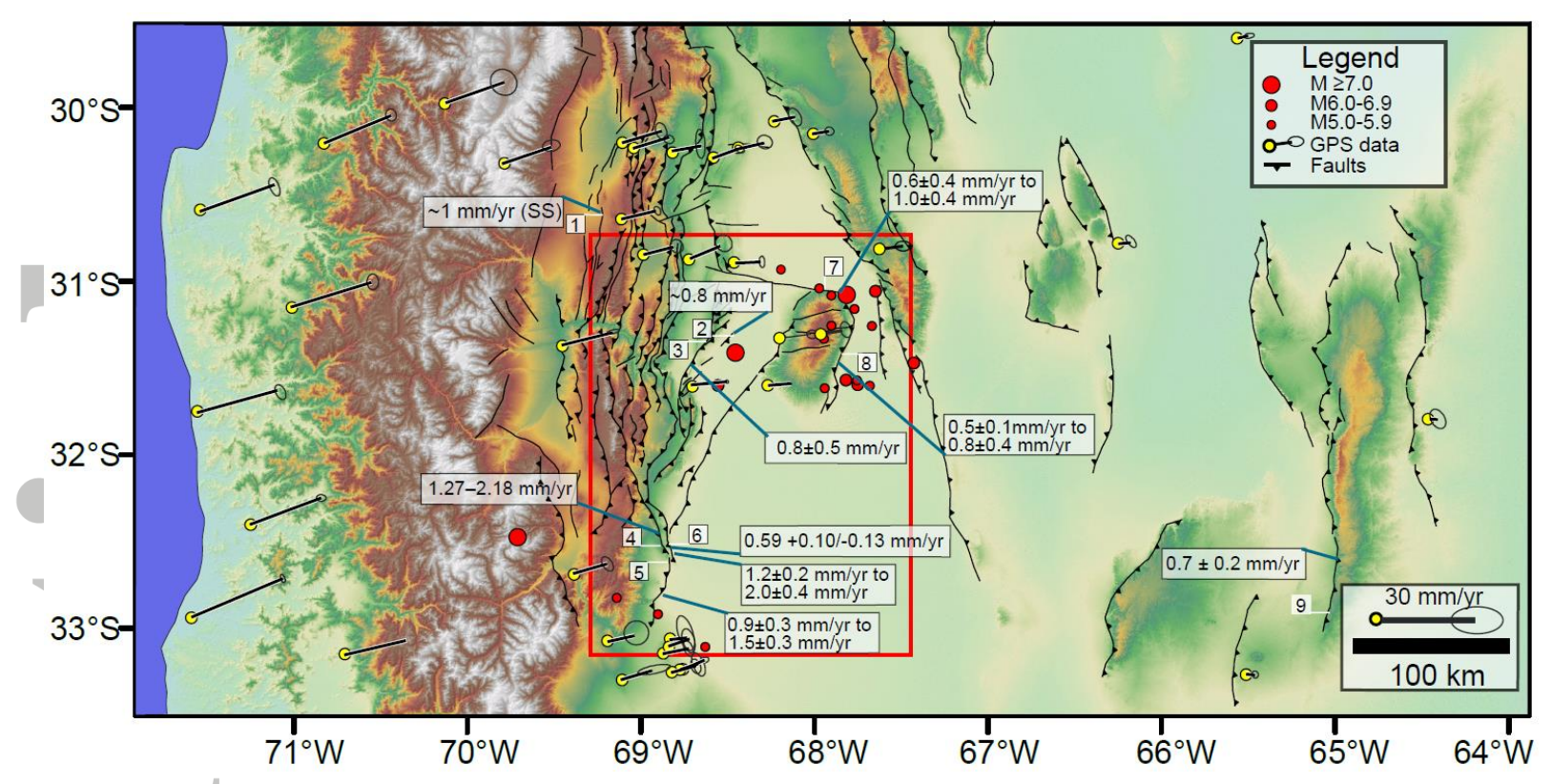

Figure 2. 30-meter ASTER digital elevation model showing tectonic features (Costa et al., 2000 and Siame et al., 2002), seismicity (Engdahl and Villaseñor, 2002), GPS velocity field (Brooks et al., 2003), and Quaternary slip rate data (Costa et al., 2015a\&b, 2018; Rockwell et al., 2014; Salomon et al., 2013; Schmidt et al., 2011; Schoenbohm et al., 2013; and Siame et al., 2002, 2006, 2015) in the Pampean flat slab segment. The red box shows the location of figure 3. Numbers in white boxes indicate faults with known slip rates: 1-El Tigre Fault, 2-La Laja Fault 3-Las Tapias segment of Villicum-Zonda-Pedernal Thrust, 4-Las Higueras 5-La Cal Thrust, 6-Las Peñas Thrust, 7-Northern Sierra Pie de Palo Fault, 8- Southern Sierra Pie de Palo Fault, and 9- Los Molinos branch of the Comechingones fault. SS, for strike-slip, denotes strike-slip rates. 


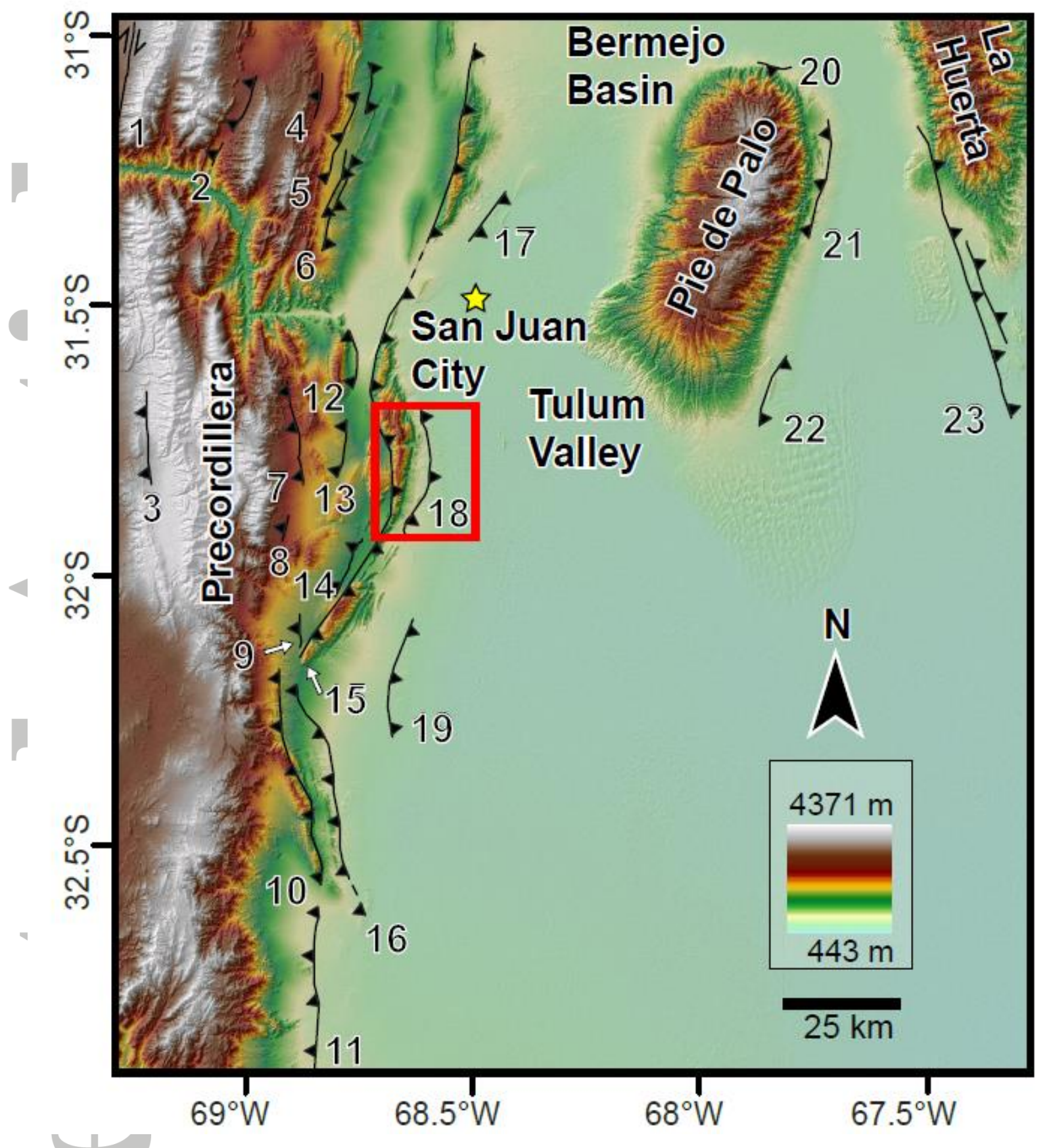

Figure 3. Quaternary faults in the provinces of San Juan and Mendoza. The red box shows the location of figure 5. Numbers indicate the Quaternary faults: 1-El Tigre, 2-La Cantera, 3-Ansilta-Jarillal, 4-Los Gauchos, 5-Dehesa, 6-Blanquitos, 7Maradona, 8-Las Osamentas, 9-Acequion, 10-Las Higueras, 11-La Cal, 12Cerro Zonda, 13-Papagallos, 14-Cerro La Chilca, 15-Villicum-Zonda-Pedernal, 16-Las Peñas, 17-La Laja, 18-La Rinconada, 19-Cerro Salinas, 20-Northern Sierra Pie de Palo, 21-Ampacama, 22-Niquizanga, and 23-Las Chacras (Costa et al., 2000; Perucca and Vargas, 2014; https://sara.openquake.org/; and http://sigam.segemar.gov.ar/visor/). 

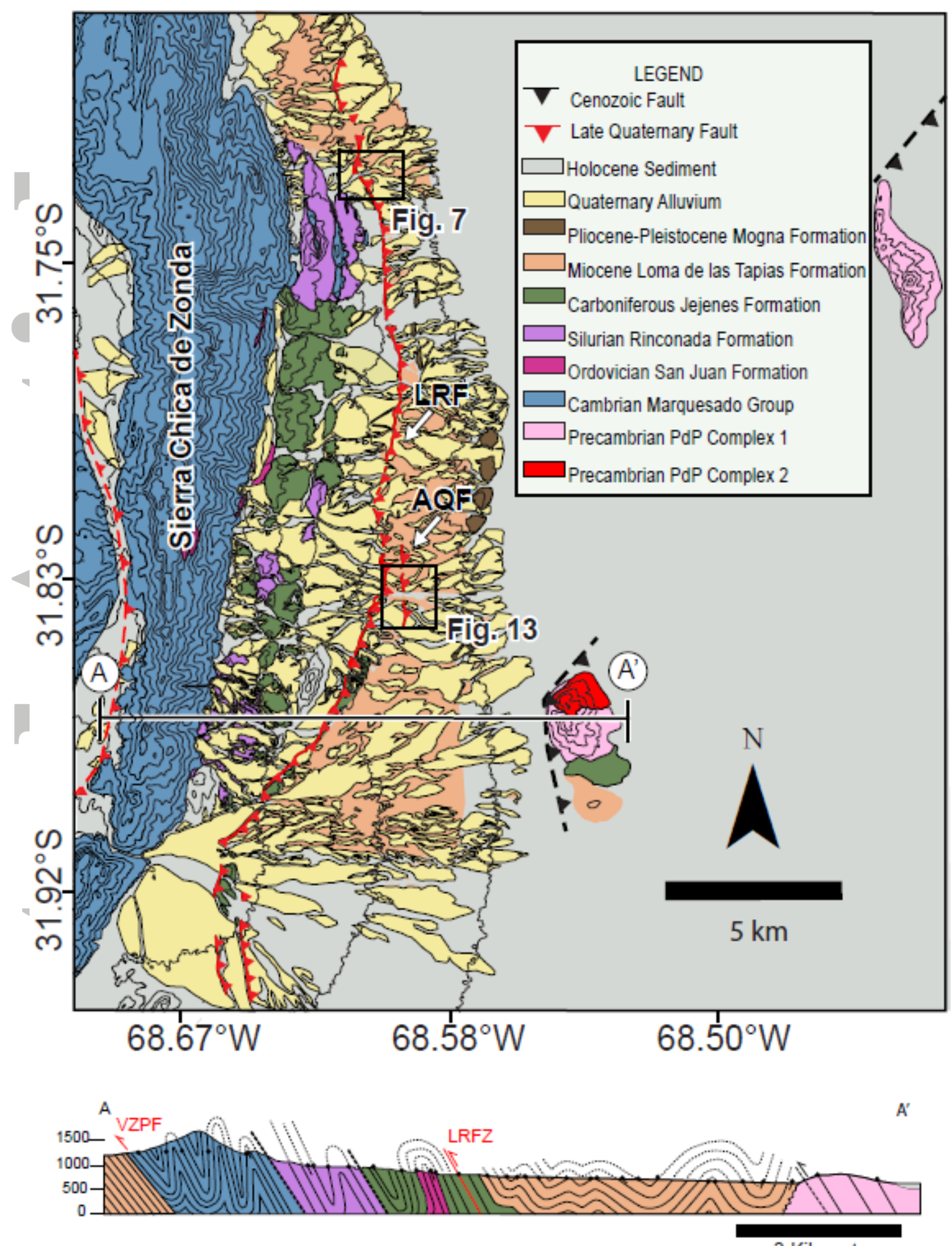

3 Kilometers

Figure 4. Geologic map and cross sections across the La Rinconada Fault Zone and the Villicum Zonda Pedernal Fault (Ramos and Vujovich, 2000; Moreno, 2013; and Richard, 2013). Black boxes labelled 'Fig. 7' and 'Fig. 13' indicate the locations of the El Molino and Arbol Quemado sites, respectively. 'PdP' in the legend stands for Pie de Palo. 


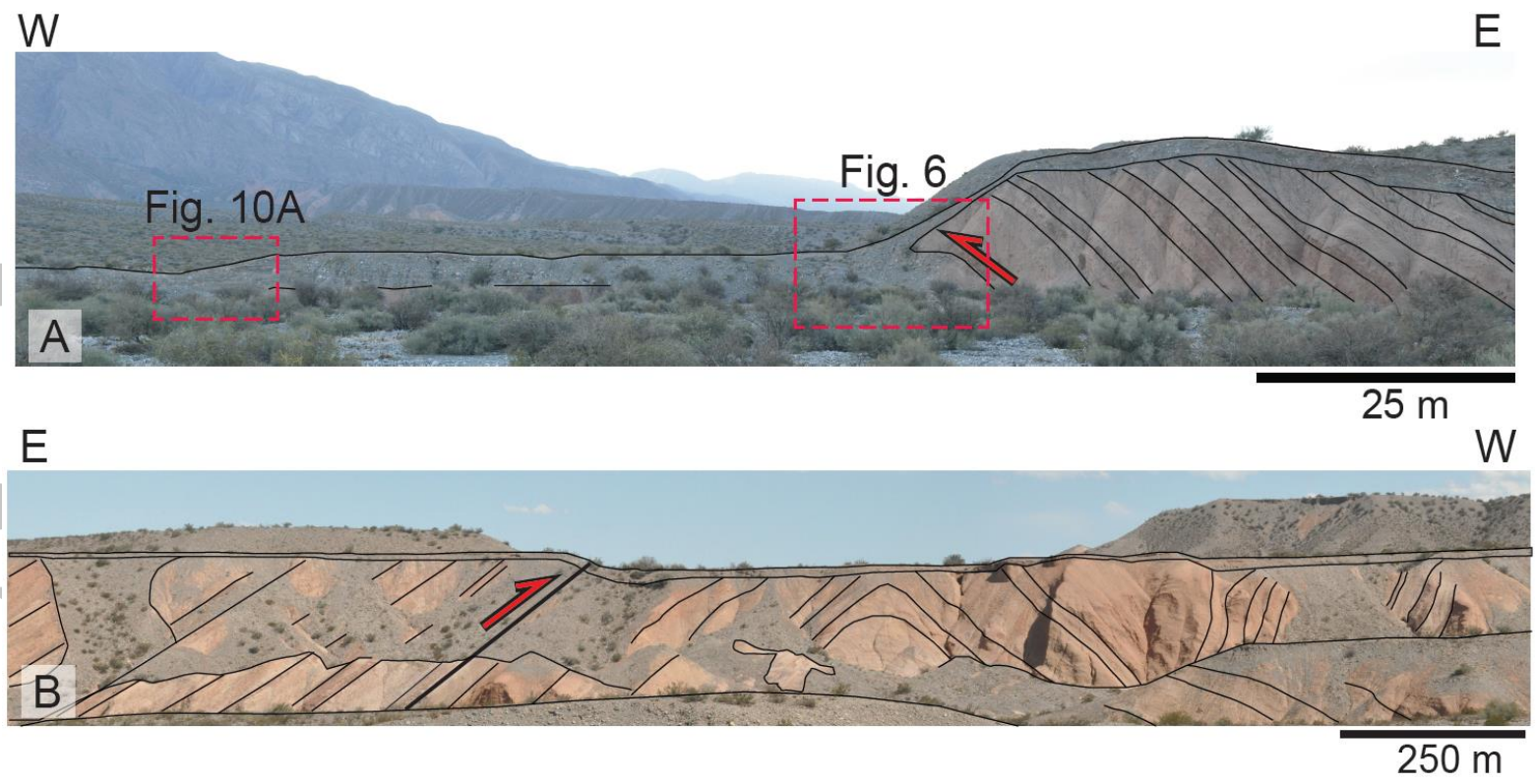

Figure 5. Exposures of the LRFZ. A. A fault propagation fold scarp to the west (shown in detail in Fig. 10A) and the main fault scarp of the La Rinconada Fault to the east (shown in detail in Fig. 6) at the El Molino site. B. The minor Arbol Quemado fault. Site locations are shown in Fig. 4. 

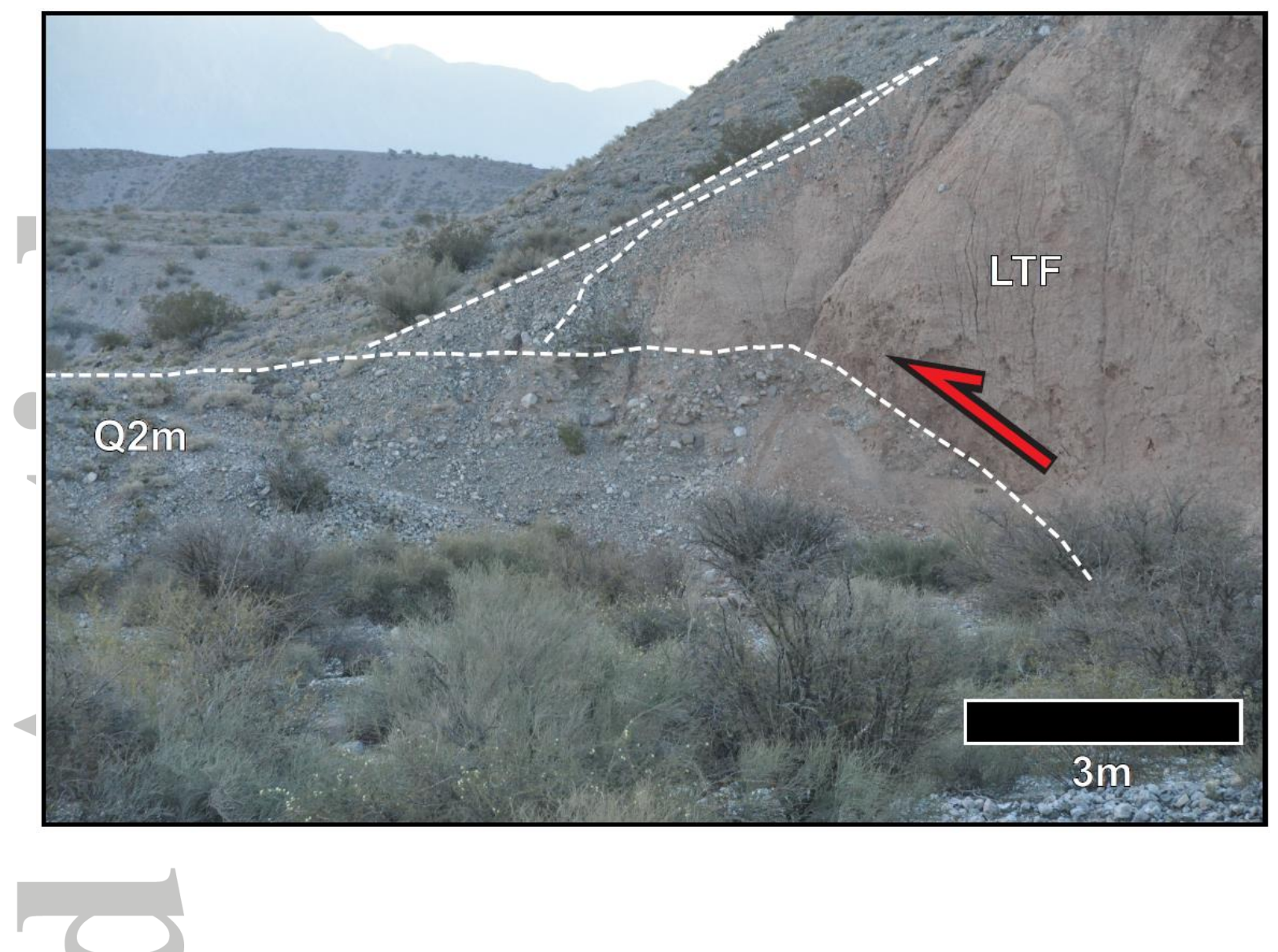

Figure 6. View of the natural river exposure of the LRFZ at the El Molino site of Figure 4A, showing the Lomas de las Tapias Formation (LTF) thrust over the $~ 34.5$ ky-old Q2m surface.

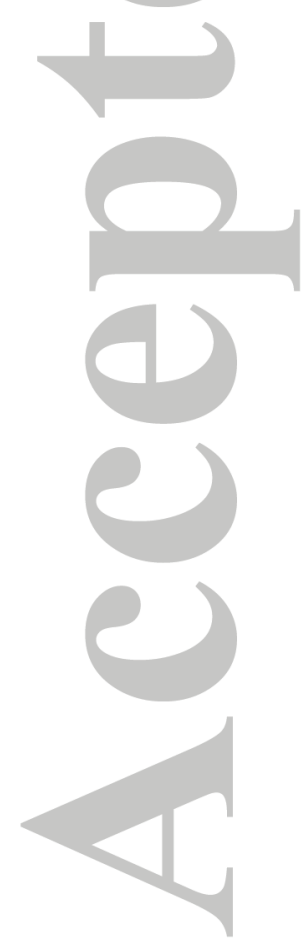

(C) 2019 American Geophysical Union. All rights reserved. 

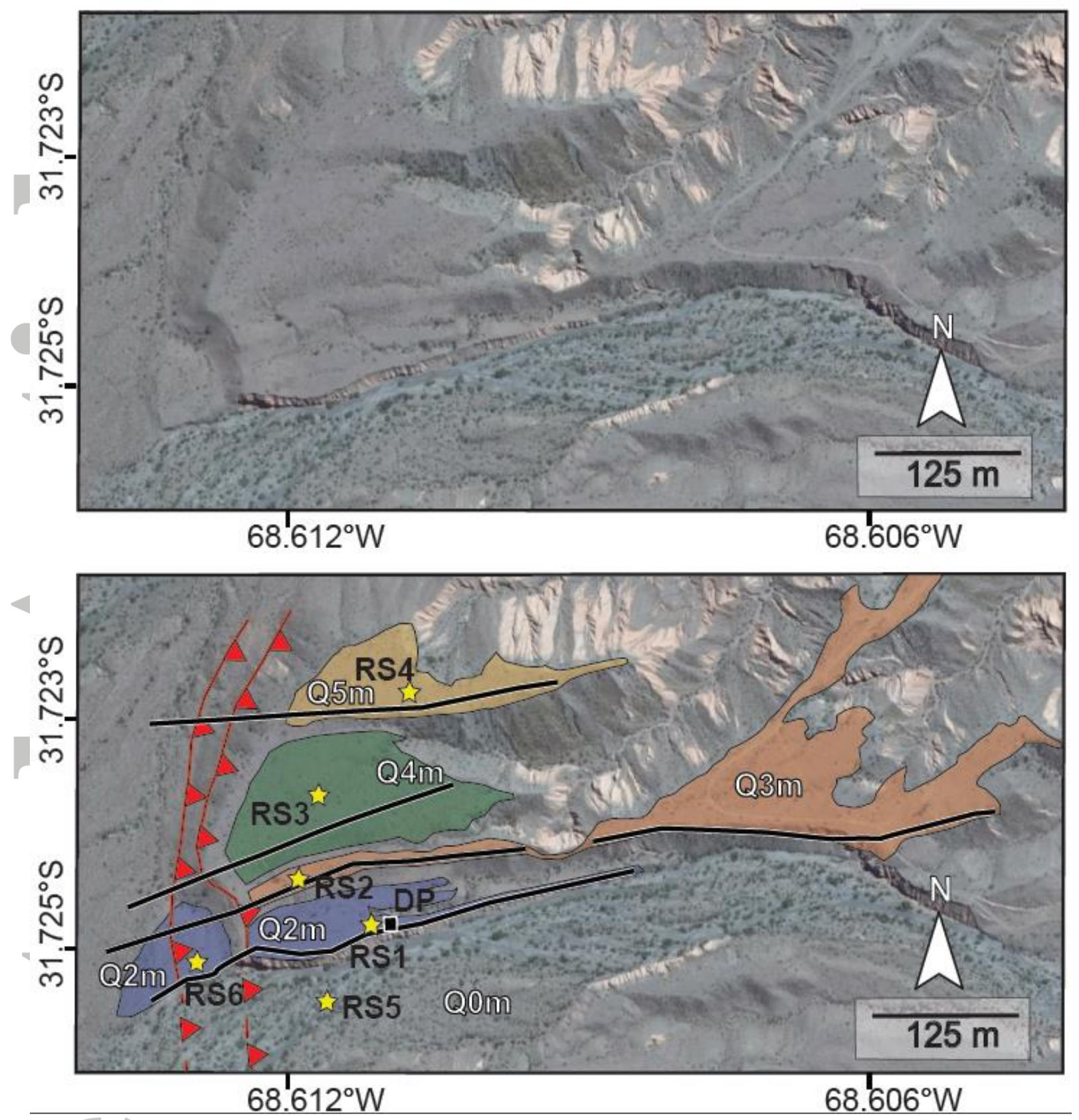

Figure 7. View of faulted strath and fill terraces in the El Molino site superimposed on a Google Earth image (Copyright Google Earth). Black lines show location of topographic profile survey lines, stars indicate ${ }^{36} \mathrm{Cl}$ surface sample locations, and black square labelled DP indicates ${ }^{36} \mathrm{Cl}$ depth profile location.

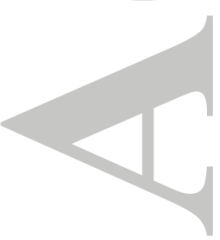




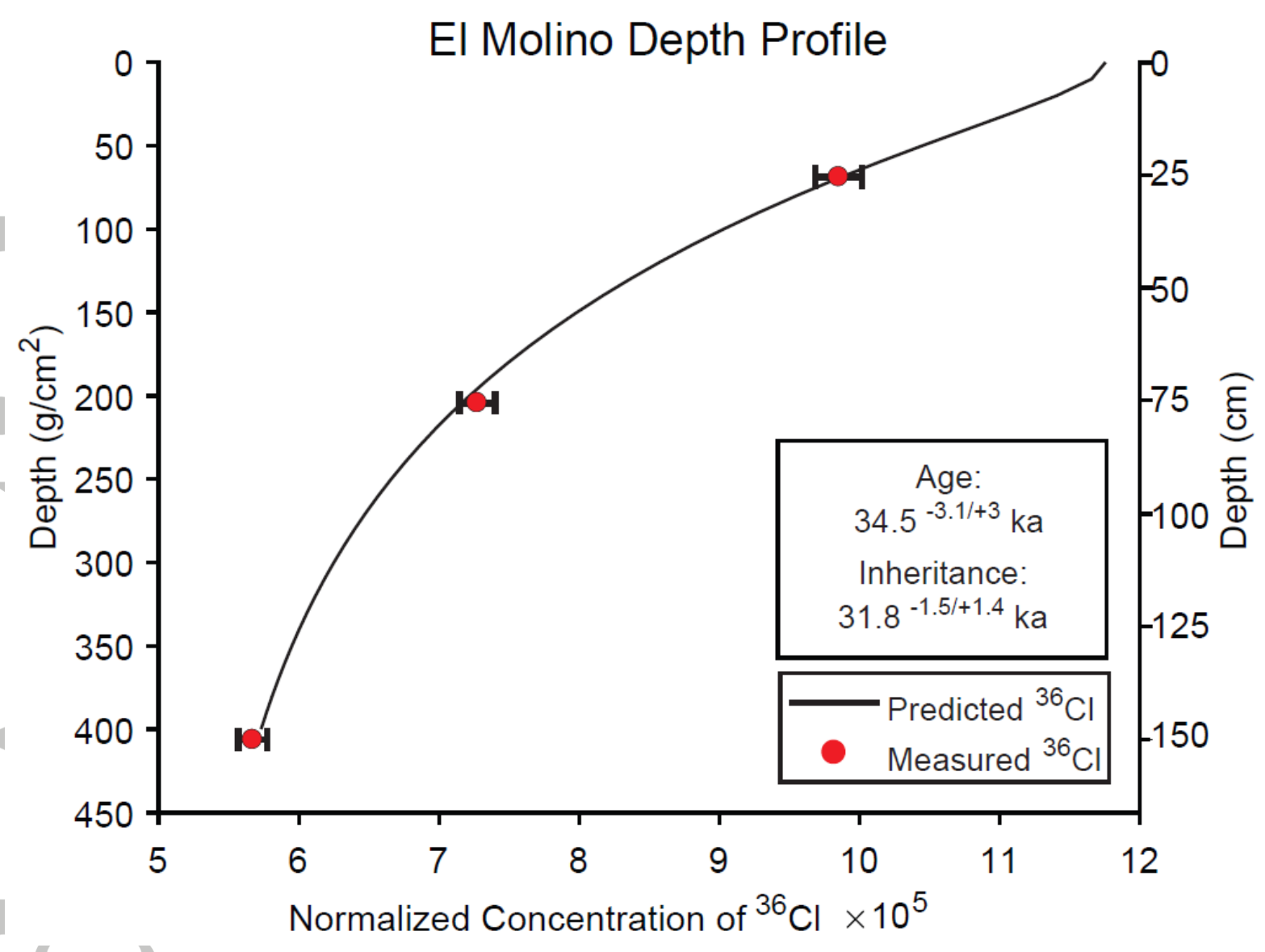

Figure 8. El Molino site ${ }^{36} \mathrm{Cl}$ depth profile. 


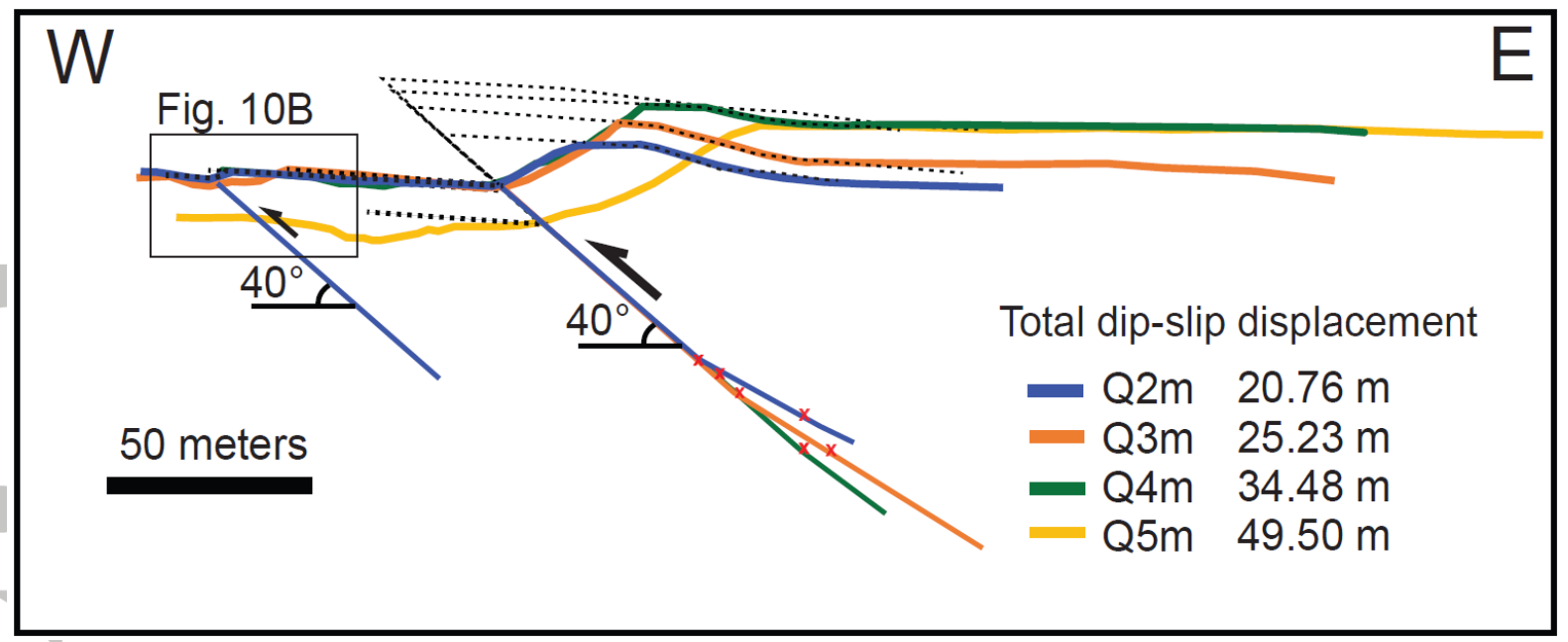

Figure 9. Forward models (dashed lines) and actual profiles (colored) of fault scarps with backlimb tilting used to constrain offset of the La Rinconada Fault in the El Molino site. Trishear parameters for these models are shown in Table 3. Displacement on Q2m reflects the sum of the displacement on the main scarp (i.e., $16.56 \mathrm{~m}$ ) and the fault propagation fold (i.e., $4.20 \mathrm{~m}$ ). Base of Q5m scarp was aligned to Q2m-Q5m during modelling of displacement. See Figure 7 for profile locations. 


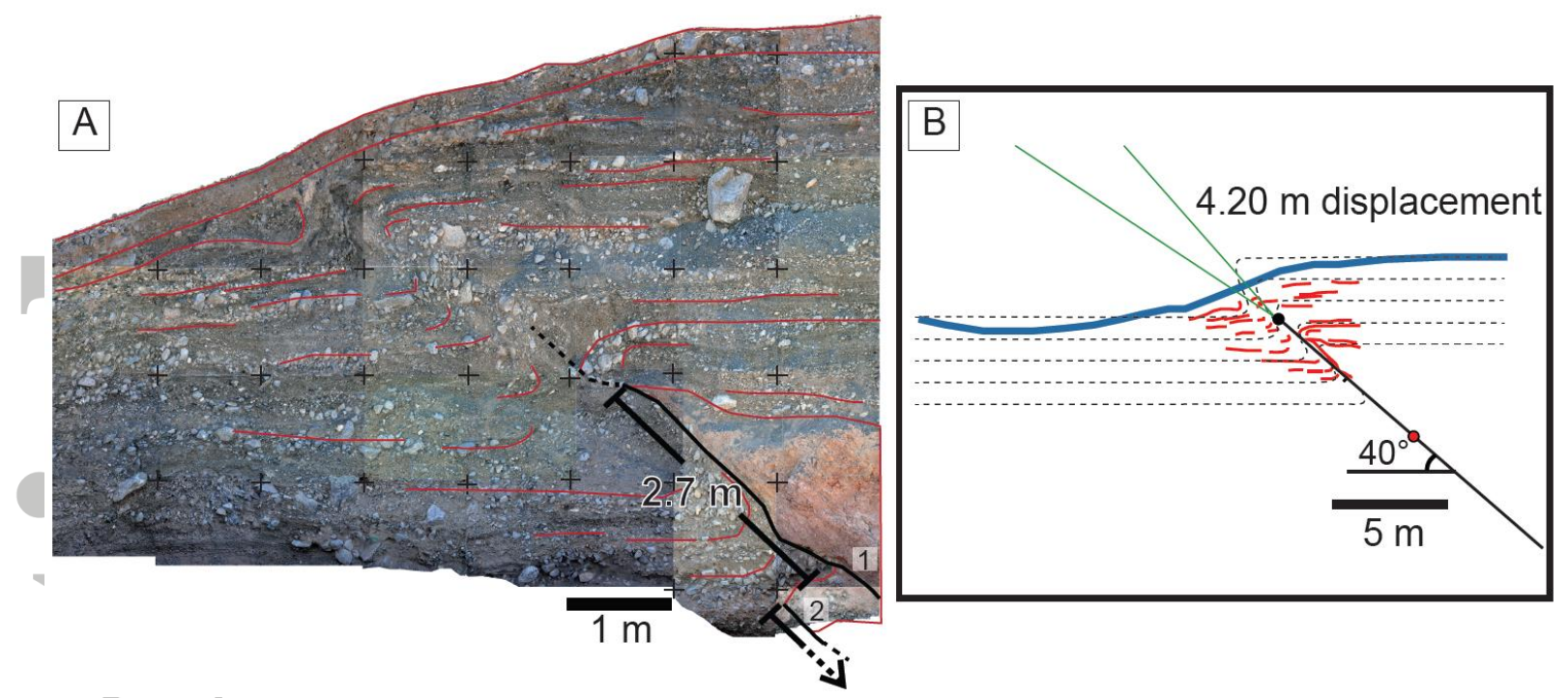

Figure 10. El Molino fault propagation fold. A. A trench photomosaic (looking north) revealing the fault-propagation fold nature of the recent scarps of the La Rinconada Fault zone. Fault strands (thin black lines) are labelled ' 1 ' and '2'. Location of trench is shown on figure 5A. B. A forward model fitting the scarp height exhibited by the topographic profile (blue line) and deformation fabric (red lines) of the El Molino fault propagation fold. The red and black dots correspond to the initial and final fault tip positions, respectively, and the green lines show the trishear apical angle $\left(15^{\circ}\right)$. This model exhibits $4.20 \mathrm{~m}$ of dip-slip displacement. 


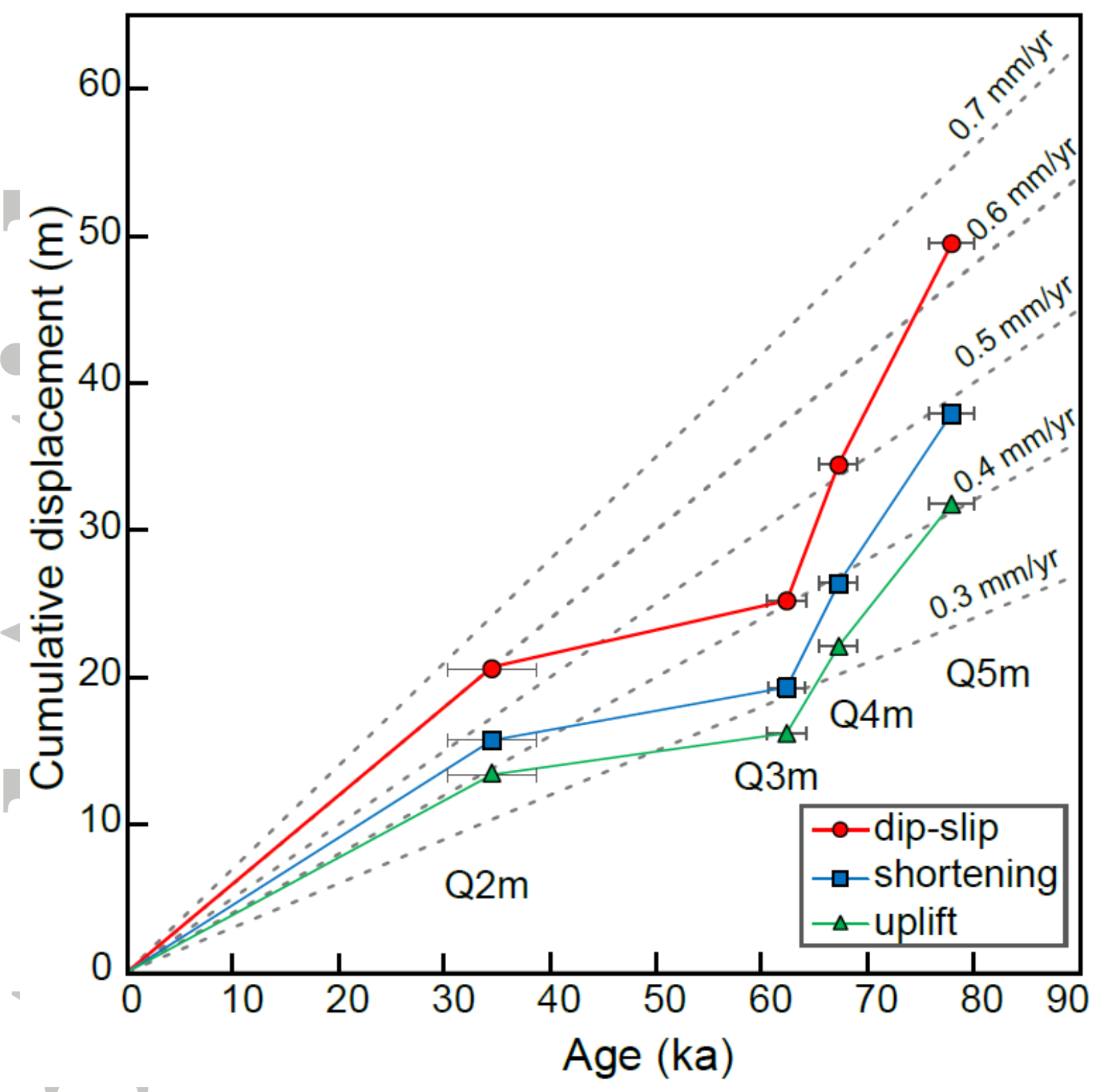

Figure 11. Plot of dip-slip and shortening and uplift components of cumulative displacement against age for surfaces Q2m, Q3m, Q4m, and Q5m. 


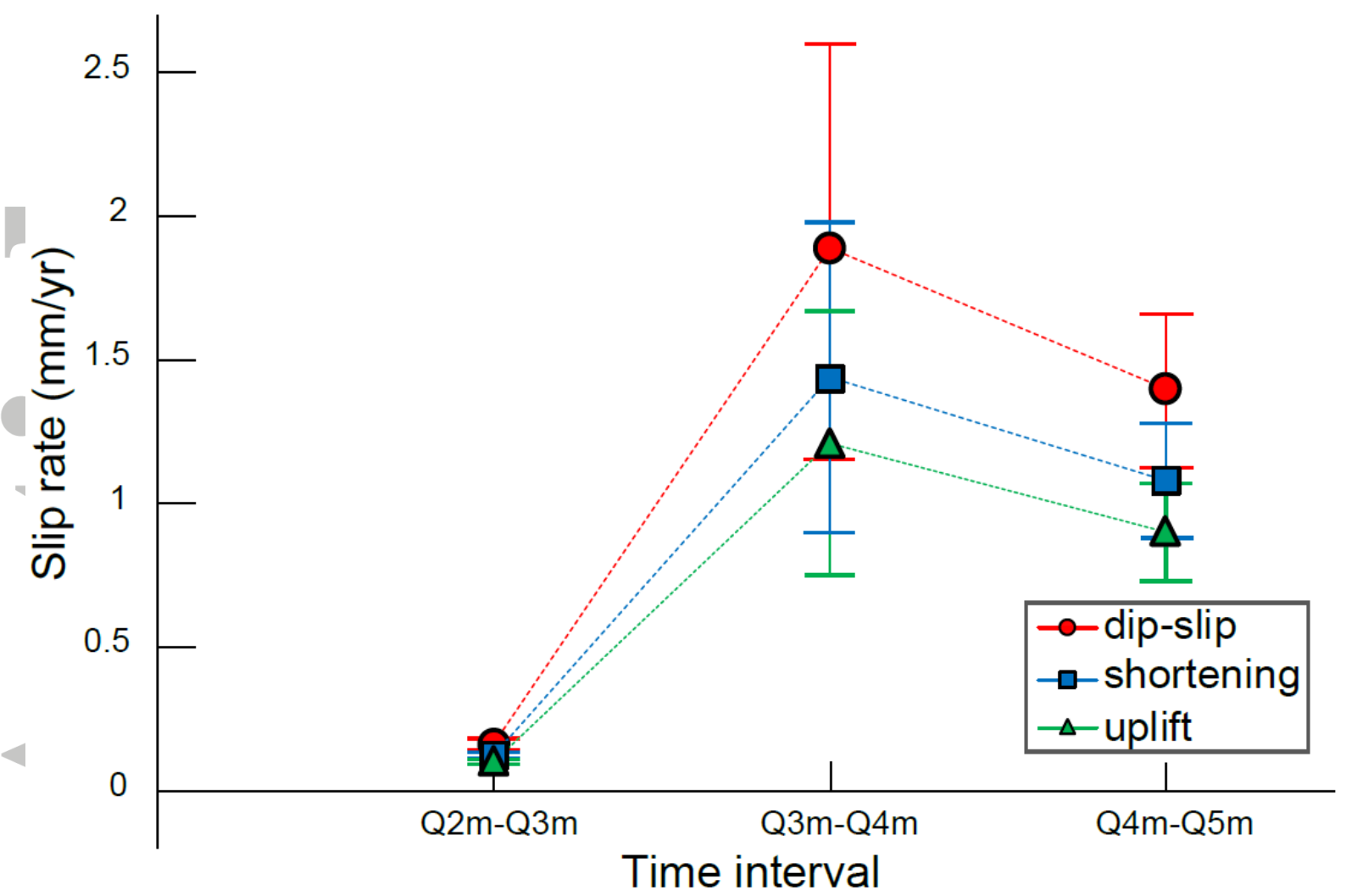

Figure 12. Plot of dip-slip and shortening and uplift components of displacement against slip rate for the intervals Q2m-Q3m, Q3m Q4m, and Q4m-Q5m. 

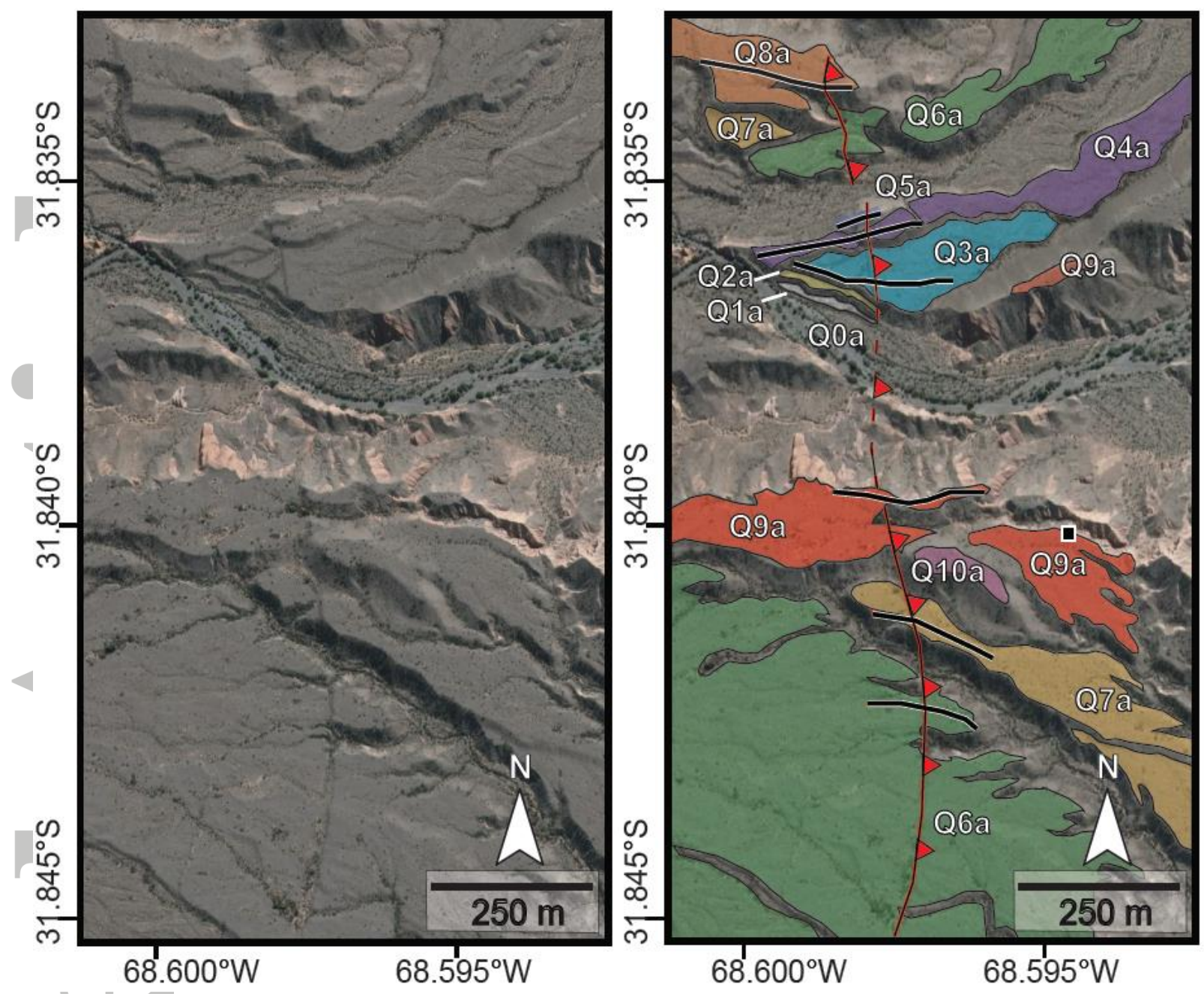

Figure 13. Faulted strath terraces in the Arbol Quemado site superimposed on Google Earth image (copyright Google Earth). Black lines show location of topographic profile survey lines and black square indicates ${ }^{36} \mathrm{Cl}$ depth profile location. 


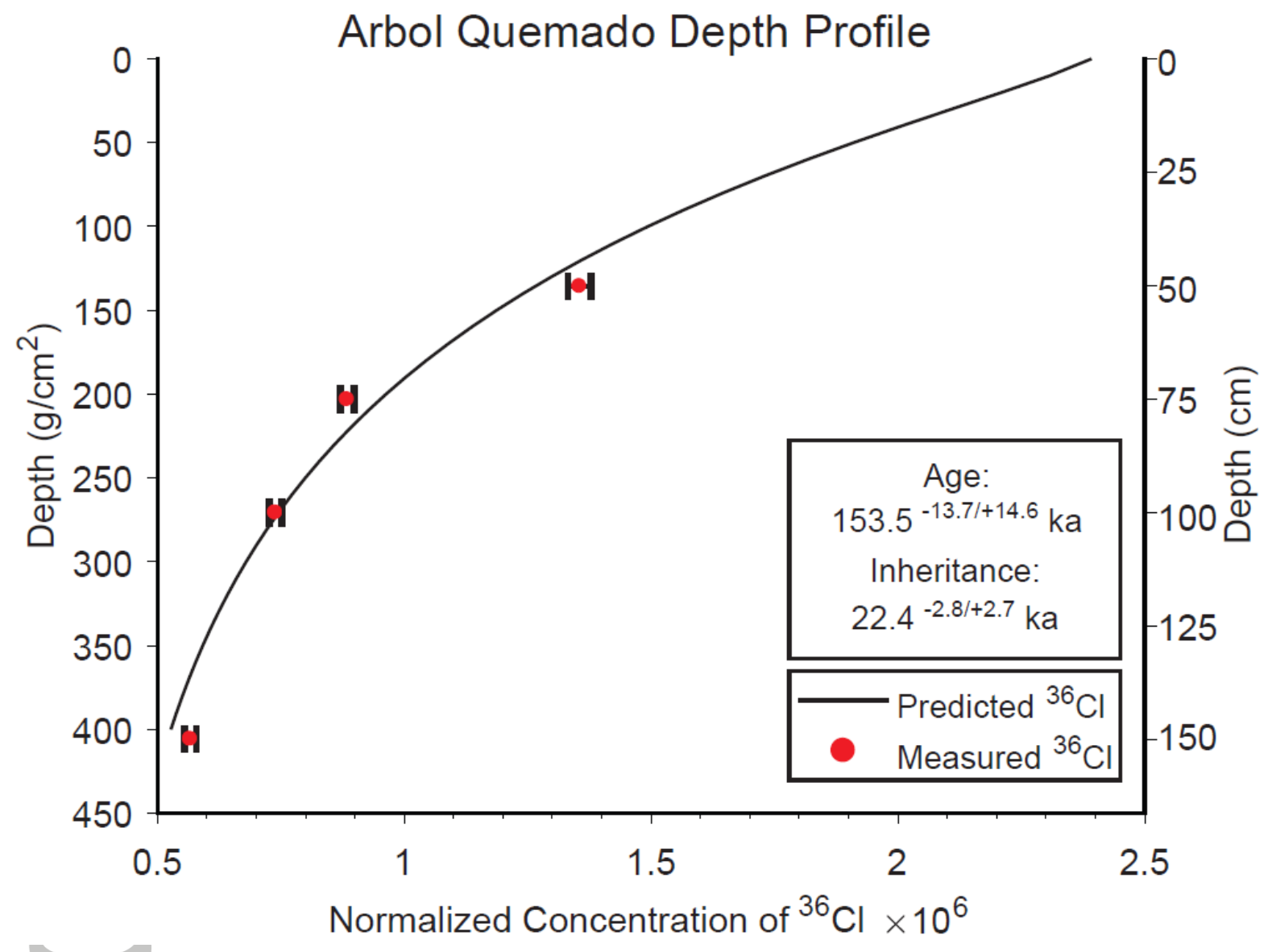

Figure 14. Arbol Quemado site ${ }^{36} \mathrm{Cl}$ depth profile. 


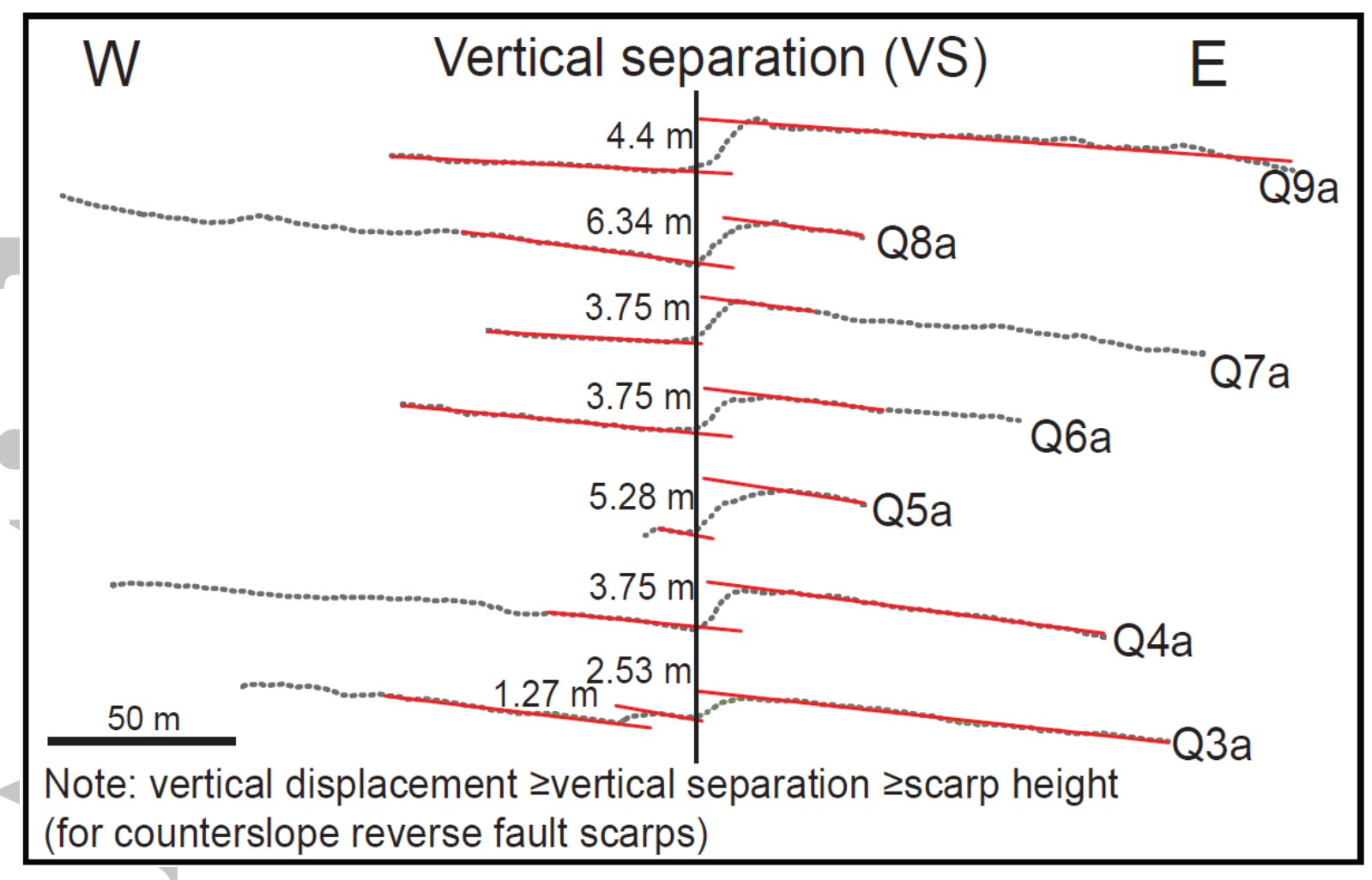

Figure 15. Topographic profiles used to constrain offset of the Arbol Quemado Fault (vertical positions of profiles are relative and do not correspond to their actual elevation differences; with 1.5 vertical exaggeration). Geomorphic surface slopes and a field observed fault angle of $33^{\circ}$ are used to reconstruct original fault geometry and calculate both uplift and shortening using equations in Yang et al. (2015). See Figure 13 for profile locations. 


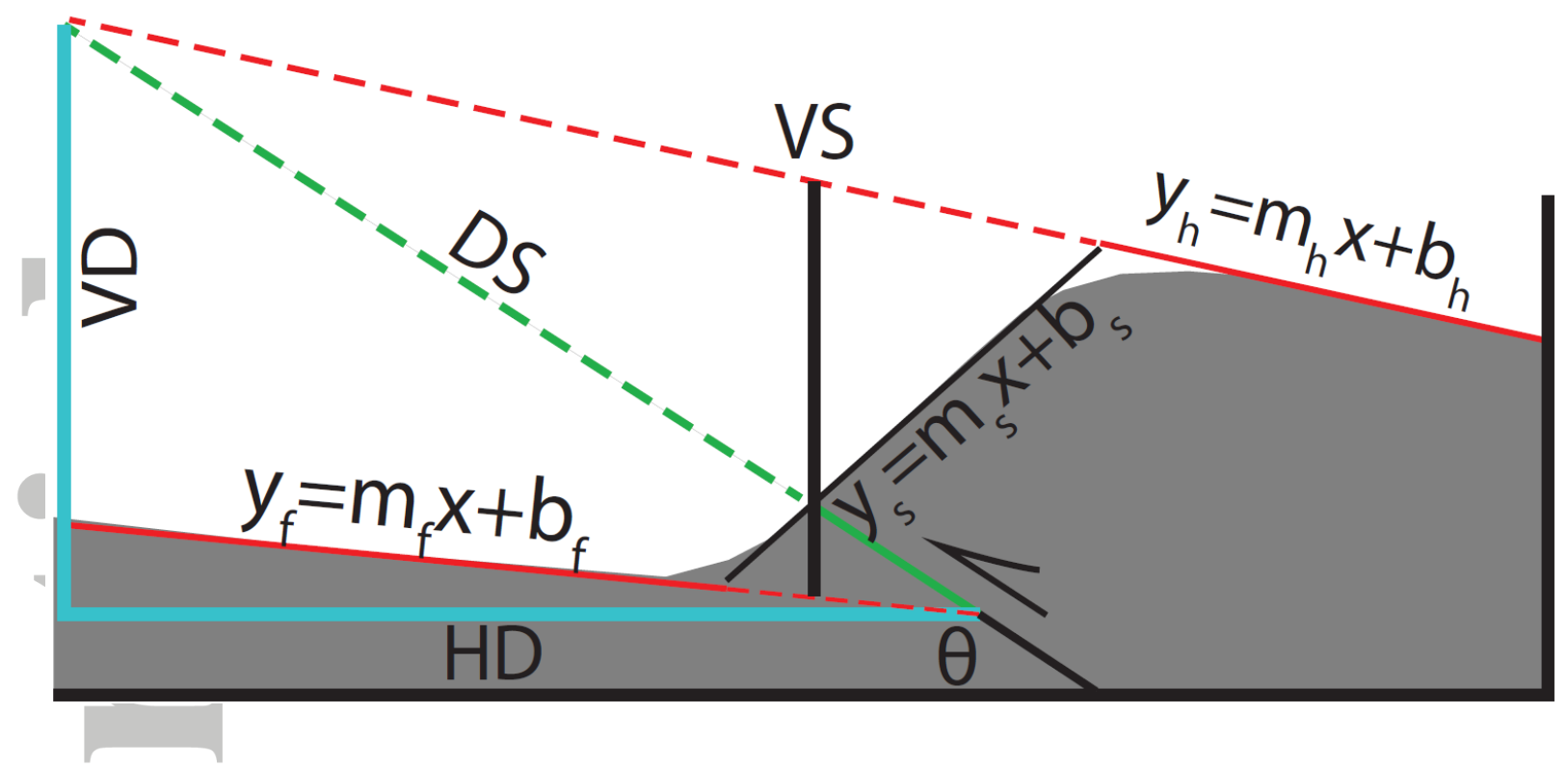

Figure 16. Theoretical fault profile and linear regressions of topographic survey points on the upthrown and downthrown surfaces (solid red for actual surface and broken red line for projection) and the scarp (black solid line). Linear regression parameters ( $m$ slope and $y$-intercept) along with dip $(\Theta)$ of fault (green line for actual plane and broken green line for projection) were used for calculating vertical displacement (VD)/uplift and horizontal displacement (HD)/shortening (blue solid line). 